\title{
Effects of Ownership on Hospital Efficiency in Germany
}

\author{
Oliver Tiemann, Munich School of Management, Ludwig-Maximilians-Universität München and Helmholtz Zentrum München, Germany \\ E-Mail: tiemann@bwl.lmu.de \\ Jonas Schreyögg, Munich School of Management, Ludwig-Maximilians-Universität München and Helmholtz Zentrum München, Germany \\ E-Mail: schreyoegg@bwl.lmu.de
}

\begin{abstract}
The objective of our study was to evaluate the efficiency of public, private for-profit, and private non-profit hospitals in Germany. First, bootstrapped data envelopment analysis (DEA) was used to evaluate the efficiency of a panel $(n=1,046)$ of public, private for-profit, and private non-profit hospitals between 2002 and 2006. This was followed by a second-step truncated linear regression model with bootstrapped DEA efficiency scores as dependent variable. The results show that public hospitals performed significantly better than their private for-profit and non-profit counterparts. In addition, we found a significant positive association between hospital size and efficiency, and that competitive pressure had a significant negative impact on hospital efficiency.
\end{abstract}

Keywords: public hospitals, ownership, data envelopment analysis, performance measurement, nonparametric technique, truncated regression, Germany

Manuscript received September 23, 2008, accepted by Peter Walgenbach (Management) September 29, 2009.

\section{$1 \quad$ Introduction}

A considerable number of empirical studies have investigated whether public, private for-profit, and private non-profit hospitals differ in terms of efficiency. However, most of these studies have data and methodological problems limiting the generalizability of the findings. Furthermore, none of the studies has considered parameters for the quality of care together with the number of cases as traditional output parameter. The German hospital sector is large, and several different ownership types have coexisted for decades, making this a fruitful field for studying the effects of ownership on efficiency. Because of increasing cost pressure, the hospital sector in Germany has been subject over the past two decades to a variety of healthcare reforms aiming to stabilize expenditures at sustainable levels. The most significant reform in recent years was the introduction of a new system of reimbursement based on diagnosis-related groups (DRGs). The chief motivation behind this fundamental overhaul of the old reimbursement system, which was based on perdiem charges, was to set financial incentives that would increase the efficiency of German hospitals (Schreyögg, Tiemann, and Busse 2006).

Due to substantial overcapacities and the rapid changes currently taking place in the regulatory and competitive environment, the German hospital sector is now facing an extensive process of consolidation and reorganization. In this context, hospitals are considering mergers, acquisitions, and cooperative agreements as ways to improve competitiveness. Over the past decade, the total number of hospitals in Germany has decreased and a growing number of hospitals have been privatized. Although there are several possible reasons for this development, the main driver has been the need to increase hospital efficiency (Megginson, Nash, and van Randenborgh 1994).

The objective of the present study was to evaluate the relative efficiency of public, private for-profit, and private non-profit hospitals in Germany. To do 
so, we used a bootstrapped DEA approach followed by a second-step truncated linear regression model while controlling for patient heterogeneity and exploring the impact of hospital organizational and environmental characteristics. Failing to take proper account of these characteristics can lead to seriously flawed conclusions (Fried, Knox Lovell, Schmidt, and Yaisawarng 2002).

The paper is structured as follows. The next (i.e. second) section reviews the relevant theoretical and empirical literature on the effects of ownership on efficiency and quality of care. The third section presents the setting, data, and methodology used in this paper to explore this relationship. The fourth section describes and discusses the estimated results, and the final section draws conclusions and makes suggestions for future research.

\section{Theoretical and empirical background}

The hospital industry in Germany is a fruitful field for studying the effects of ownership on hospital performance. It is one of the few sectors where different types of ownership have co-existed for decades, and it is large, ensuring an appropriate sample size. When selecting a central performance criterion for our analysis, we followed the example of other theoretical and empirical studies that have dealt with the comparison of ownership types. Standard performance measures such as return on investment and profitability were found to be inappropriate for public and private non-profit entities (Leibenstein 1966; Feldstein 1967; Rees 1988; Pestieau and Tulkens 1990). Consequently, we focus our analysis on technical efficiency, which is a key concept in measuring performance as it refers to the optimal use of resources in the production process. In particular, technical efficiency (i.e. productive efficiency) is a measure of how well an organization produces output from a given amount of input, or alternatively produces a given amount of output with minimum quantities of inputs. In order to address a key limitation of existing studies, our study examines both the productive efficiency implications and patient health outcomes (i.e. quality of care) of hospital ownership. There have been many theoretical contributions on the effects of hospital ownership on efficiency and quality of care. The following discussion highlights the main arguments.

\subsection{Theoretical Perspectives and Development of Hypotheses}

By ownership, hospitals can be generally divided into private hospitals (i.e. private for-profit and private non-profit), invested and owned by private entities (i.e. individual or several private owners) and public hospitals, invested and owned mainly by public entities such as governments. Agency theory and property-rights theory, as well as public choice theory provide different explanations for a common outcome. Private for-profit ownership, they hypothesize, is superior to public and private nonprofit ownership because private for-profit ownership is associated with a higher productive efficiency. These theories emphasize that differences in efficiency are due to substantial dissimilarities in objectives, incentives, and control mechanisms between ownership types. The following discussion highlights the main arguments.

The agency theory assumes that managers (or agents) seek to maximize their own utility rather than that of the organization or its owners (or principals). As a result, in all three types of hospital ownership owners face a principal-agent problem with those whom they hire to do the managing. Although both public and private hospitals face this problem, it is assumed that private for-profit hospitals have better means to solve the principal-agent dilemma and therefore their performance in terms of productive efficiency is expected to differ significantly. The owners of a profit-seeking hospital have profits as their measure of the manager's success. The owner can limit divergences from his interest, by making the manager's compensation a positive function of the profits (i.e. a correlation between profits and managerial salaries and promotions). In addition, the income of executive physicians in private for-profit hospitals might also be tied to hospital's financial performance. Within the public and private non-profit hospitals, individual decision makers rarely have their income tied to the hospital's performance (e.g., pay scales designed for civil servants); therefore no individual has a strong incentive to enforce efficient behavior. Accordingly, it is expected that private for-profit hospitals realize a higher level of efficiency than their public and private non-profit counterparts (Reder 1965; Rice 1966; Newhouse 1970; Lee 1971; Pauly and Redisch 1973; Foster 1974; Sloan 1976; Fama and Jensen 1983; Jacobs and Rapoport 2003). 
According to the property-rights theory, ownership of a firm involves two essential rights: (1) the right to control the firm and (2) the right to appropriate the firm's profits (i.e. financial surplus). Accordingly, the defining difference is that public and nonprofit hospitals are precluded from distributing, in financial form, its surplus to those in control of the organization (i.e. non-distribution constraint). Within for-profit hospitals, assigning some of the financial surplus to the individual who manage the hospital thus provides a way to monitor his activities. In this case, it is expected that the monitoring is automatic and self-imposed by the manager and that managers will have strong incentives to behave in the interests of the owners (Jacobs 1974; Clarkson 1972; Hansmann 1988). In addition, potential divergences of interests between owners and managers in private for-profit organizations are further reduced by external mechanisms, including (a) a market for ownership rights that enables the owners to sell their shares if they are not satisfied with managerial performance; (b) the threat of takeover; (c) the threat of bankruptcy; and (d) an extensive managerial labor market (Villalonga 2000). Thus, property-rights theory assumes that private forprofit ownership is associated with a higher efficiency compared to the other types of ownership.

As part of public choice theories Buchanan and Tollison (1972), Niskanen (1975), and Shleifer and Vishny (1994) argue that politicians impose their objectives on public organizations in order to gain votes, which may conflict with profit maximization and, therefore, with productive efficiency. In the case of private non-profit providers Newhouse (1970) and Weisbrod (1988) argue that, because they lack the incentive to maximize profit, they should be expected to diverge from strict cost- or inefficiency-minimizing behavior and instead maximize quality, quantity, and/or prestige. Sloan (2000) supports this view and adds that productive efficiency will decay if objectives are vague and contradictory, which is typically the case in public and private non-profit hospitals.

According to the theories mentioned above, private for-profit hospitals are expected to maximize profits on the basis of a high level of productive efficiency. It is emphasized that dissimilarities in efficiency and quality of care are due to substantial differences in objectives, incentives, and control mechanisms. Owners may differ as some are more willing to supply more than the profit-maximizing services than are others. Such hospitals produce services that are not likely to be produced by a for-profit institution, unless, of course, dedicated subsidies exist for these services (e.g., supplementary for highly specialized services or centers in Germany). A profitmaximizing hospital will produce services to the point where the marginal costs equal the marginal revenue. Public and private non-profit hospitals will expand their output at least to the point where the hospital just breaks even - that is, where the total cost equals total revenue. Much of the rationale for public and private non-profit hospital ownership is based on the welfare implications of these ownership types (Hall 1995; Steinberg 2006; Rathgeb Smith and Gronbjerg 2006).

Hypothesis 1: Private for-profit hospitals are more efficient than private non-profit and public hospitals.

The character of the services that are provided by hospitals implies that quality of care is one major objective for hospitals in addition to efficiency. For the hospital sector, a common theoretical assumption is that better quality of care requires more resources and therefore reduces efficiency. It is further assumed that due to information asymmetries between hospitals and other actors (e.g., patients and purchasers) hospitals may be able to vary their quality of care (Newhouse 1970; Weisbrod 1988). However, differences in the trade-off between productive efficiency and quality of care among public and private non-profit providers have attracted little attention from a theoretical point of view. Given the strong efficiency focus of private for-profit providers it is argued that due to the trade-off those hospitals offer a lower quality of care than hospitals of other ownership types. In contrast, private non-profit and public hospitals allow more room for objectives other than efficiency and are therefore able to provide a higher quality of care than private for-profit hospitals.

Another group of theorists argues that particularly physicians represent a group that is typically acting driven by high intrinsic motivation (Arrow 1963; Zismer 1999; Feess and Ossig 2007). Thus, physicians are intrinsically motivated to deliver high quality of care. The enhanced behavioral discretion conditioned by the non-distribution constraint of public and private non-profit hospitals might provide a fruitful field for intrinsic motivation of physicians to act in the patient's best interest. In contrast, 
the extrinsic motivation conditioned by financial incentive schemes usually provided in private forprofit hospitals can be expected to result in a crowding out of intrinsic motivation (Osterloh and Frey 2000; Frey and Jegen 2001). This effect lends support to the notion that private for-profit hospitals provide a lower quality of care. However, as physicians have to act in accordance with regulations and ethical rules (e.g., clinical guidelines, Hippocratic Oath) a certain minimum standard of quality of care will be ensured.

Hypothesis 2: The efficiency differences between ownership types will decrease if quality of care is taken into account to determine efficiency (i.e. quality-adjusted efficiency) due to an inevitable trade-off between efficiency and quality of care.

\subsection{Empirical Evidence}

There is a rich body of literature on hospital performance in the United States and Europe. Two major reviews have been published in recent years. Hollingsworth (2008) reviewed the literature on frontier efficiency measurement techniques in healthcare. From the early 1980s up to mid-2006 a total of 317 studies had been published, almost $80 \%$ of which made use of non-parametric DEA while most of the other studies used parametric stochastic frontier analysis (SFA). Reviewing the studies on efficiency differences of hospital ownership Hollingsworth found 39 studies and concluded that public hospitals in Europe and the United States appear to be more efficient than their private forprofit and non-profit counterparts. Shen, Eggleston, Lau, and Schmid (2007) applied meta-analytic methods to conduct a quantitative review of the empirical literature on hospital ownership published between January 1990 and July 2004 (i.e. 16 empirical studies). The authors concluded that ownership had an impact on efficiency, but the conventional assumption that private for-profit hospitals operate more efficiently was not supported in the review by Shen, Eggleston, Lau, and Schmid (2007), who indeed rather observed the opposite.

Taken together Hollingsworth (2008) and Shen, Eggleston, Lau, and Schmid (2007) reviewed eleven international studies that have compared all three different types of ownership in terms of efficiency. In four studies public hospitals were found to be less efficient than their counterparts (Zuckerman, Hadley, and Iezzoni 1994; Ferrier and Valdmanis 1996;
Brown 2003; Chang, Chang, Das, and Li 2004), while six studies showed that publicly owned hospitals are more efficient than private for-profit and non-profit hospitals (Ozcan, Luke, and Haksever 1992; Burgess and Wilson 1996; Koop, Osiewalski, and Steel 1997; Chirikos and Sear 2000; McKay, Deily, and Dorner 2003; Sari 2003). Burgess and Wilson (1998) found no significant efficiency differences associated with ownership. Out of these eleven studies, seven studies have a large nation-wide sample and are based on comparable large data samples (i.e. sample sizes between 382 and 4,075 hospitals). Among all eleven studies, none of the studies have used patient-level information to control for patient heterogeneity and to ensure the comparability of the observed hospitals which may be due to the lack of availability of adequate measures for patient heterogeneity between ownership types. Only two studies have used a two-stage analysis (i.e. DEA followed by some form of regression analysis), despite the fact that in recent years it has become the state-of-the-art approach (Burgess and Wilson 1998; Ferrier and Valdmanis 1996). In addition, the study periods of all eleven studies are dated back to the late 1980 os or 1990 s, thus limiting the generalizability of the results.

Empirical data on the efficiency of the German hospital sector, and especially on the effect of ownership status on hospital efficiency, are scarce. The efficiency of German hospitals has been investigated primarily using DEA. Staat and Hammerschmidt (2000) were the first to employ DEA to German hospitals, based on data of 160 hospitals in 1994 . The authors found that DEA efficiency scores differed significantly between ownership types and that private non-profit hospitals were, on the average, less efficient than their public and private forprofit counterparts. Using aggregate state-level data from 1991 to 1996, Helmig and Lapsley (2001) showed that public and non-profit hospitals appear to use relatively fewer resources than private forprofit hospitals $(n=288)$. Staat (2006) applied a refined DEA approach to the same sample of 160 hospitals for the year 1994 and found no significant efficiency differences associated with ownership. Herr (2008) employed SFA to investigate the efficiency of about 1,500 German hospitals between 2001 and 2003. Herr's empirical results for the years 2000 through 2003 indicate that private forprofit and non-profit hospitals were less efficient than publicly owned hospitals. 
Of the few studies that have investigated the efficiency of the German hospital sector to date, all have important drawbacks. One of these is the lack of detailed data, which means that the quality and the quantity of the information used to assess efficiency is often limited (e.g., aggregate state-level data, small sample size), thus limiting the generalizability of results. Another drawback of these studies is their use of DEA. From a methodological point of view, some authors argue that results of DEA analysis are much more robust when study samples are very large (Shen, Eggleston, Lau, and Schmid 2007; Jacobs, Smith, and Street 2006). All of the DEA studies that have investigated the efficiency of the German hospital sector thus far have used DEA alone without using a two-stage approach. In addition, none of the German studies used patient-level information on diagnoses, procedures, and age to control for patient heterogeneity and to ensure the comparability of the observed hospitals.

Our review of empirical studies suggests that, in contrast to the assumed behavior outlined in theory, there is no evidence that private ownership is associated with higher efficiency compared to other ownership types. In fact, our review indicates that public hospitals use relatively fewer resources than private for-profit and non-profit hospitals. In addition, none of the mentioned studies has considered parameters for the quality of care together with the number of cases as traditional output parameter. The output of the hospitals' production process has been measured in terms of physical units (e.g., number of patients treated or patient days). Although an increasing number of studies have made adjustments for case mix, the intermediate hospital outputs (i.e. number of cases) are not adjusted for final health outcomes/quality of care (e.g., mortality rates or readmission rates). One reason for this might be the paucity of validated measures of quality. The absence of quality measures requires the implicit assumption that there are no systematic variations in quality, or that variations in quality do not systematically affect efficiency. However, studies examining the trade-off between efficiency and quality of care have provided evidence of an inevitable trade-off between these two measures. Morey, Fine, Loree, Retzlaff-Roberts, and Tsubakitani (1992), Picone, Chou, and Sloan (2002) and Deily and McKay (2006) found that hospital efficiency was positively associated with the observed inhospital mortality rate.

While testing the above mentioned hypotheses we also aimed to address methodological limitations of previous studies. First, we used a two-step methodology integrating covariates representing organizational and environmental characteristics in the second stage regression that may have impact on hospital efficiency. Second, we controlled for patient heterogeneity among hospitals by including variables representing case-mix complexity. Third, we relied on a large data sample to generate robust results. Fourth, we performed a number of robustness checks to investigate the validity of our results.

\section{Research design and methods}

\subsection{Setting and Data}

In Germany, approximately 1,80o hospitals provide inpatient care and receive DRG payments from social health insurance funds and private health insurance companies. The data for our study were derived from the annual hospital reports collected and administered by the Research Data Centre of the Statistical Offices of the Länder (Forschungsdatenzentrum der Statistischen Landesämter 2008). This rich dataset covers all public, private for-profit, and private non-profit hospitals in Germany and contains hospital-level information on costs and hospital infrastructure, as well as patientlevel information on age, diagnoses, and certain procedures performed per case. Our study is based on data from the fiscal years 2002-2006, and the unit of analysis was the hospital. Because of data privacy issues, we were able to obtain randomly selected data from only two-thirds of German acute care hospitals $(n=1318)$. To ensure the comparability of the hospitals in the sample, hospitals providing only psychiatric care, day clinics, and hospitals with fewer than 50 beds were excluded from further analysis. In addition, content-based plausibility checks were conducted to reveal measurement errors. Finally, a total of 1,046 hospitals remained in the sample and due to missing values in some years our sample for the years 2002 through 2006 is based on 4,902 observations.

German hospitals can have public (PUBLIC), private for-profit (PRIVATE-FP), or private non-profit (PRIVATE-NP) ownership status. Between 1993 and 2006, the share of private for-profit hospitals 
rose from $16 \%$ to $28 \%$, whereas the share of public hospitals decreased from $43 \%$ to $34 \%$. During the same period, the share of private non-profit hospitals remained relatively constant (Forschungsdatenzentrum der Statistischen Landesämter 2008).

\subsection{First stage: Data Envelopment Analysis} In the hospital sector, data envelopment analysis (DEA) has been the most frequently used approach for measuring efficiency (Hollingsworth 2008). DEA is a linear programming technique for evaluating the relative efficiency of individual organizations based on observed data. The relative efficiency of an organization is defined as the ratio of the weighted sum of its outputs to the weighted sum of its inputs. The weights are not pre-assigned, but rather determined by the model, thus avoiding any bias resulting from subjectively assigned weights. DEA assesses the efficiency of organizations in two stages. First, the location and the shape of the efficiency frontier are determined based either on organizations that use the lowest input mix to produce their outputs or on organizations that achieve the highest output mix given their inputs. The efficiency frontier is constructed by joining these observations and all linear observations in the input-output space. In our study, we used an input-oriented DEA approach to address the following question: "To what extent can the input factors, defined as supplies and labor, be reduced proportionally without changing the output quantities of German hospitals?" Second, DEA measures inefficiency as the radial distance from the inefficient unit to the frontier and produces an efficiency score that reflects the relative efficiency of each unit (Cooper, Seiford, and Zhu 2004).

DEA allows multiple inputs and outputs to be considered simultaneously, which seems particularly well-suited for measuring the efficiency of hospitals. In contrast to parametric methods, where a specific pre-defined functional form is assumed to apply to each observation, DEA has the advantage of requiring no assumptions about the functional form of the production or cost frontier. Although this reduces the need for a theoretical exposition of the model specification, there are other important considerations. The DEA results are sensitive to the number of variables included in the model. In general, the number of inputs and outputs is limited by the sample size, which should not exceed one-third of the number of observed units (Banker, Charnes, Cooper, Swarts, and Thomas 1989). It is important to recognize that the inputs and outputs are collected routinely by hospital accounting departments, making measurement errors less relevant. Based on our understanding of the market constraints within the German hospital sector, we assumed variable returns to scale, which may be appropriate when it is impossible to assume that all observed units are operating at an optimal scale (Banker, Charnes, and Cooper 1984). In the healthcare sector, imperfect competition and budgetary constraints, as well as regulatory constraints on entry, mergers, and exits, may often result in organizations operating at an inefficient scale size (Jacobs, Smith, and Street 2006).

When selecting inputs and outputs, we followed the example of other studies that developed DEA frameworks for measuring hospital efficiency ( $\mathrm{Pi}-$ lyavsky, Aaronson, Bernet, Rosko, Valdmanis, and Golubchikov 2006; Jacobs, Smith, and Street 2006; Burgess and Wilson 1998). For the purposes of our study, six inputs and two outputs were considered. The first input variable (SUPPLIES) is the amount spent on supplies per year, including operational expenses, but excluding payroll, capital, and depreciation expenses. Taking into account the relative importance of resource use in terms of labor in the hospital production process, additional input variables were the number of full-time equivalents (FTE) for the following personnel categories: clinical staff (CLIN), nursing staff (NURS), medicaltechnical staff (MEDTECH), administrative staff (ADMIN), and other staff members (OTHER).

The first output variable (INPATIENT) reflects the number of treated inpatient cases per year in each hospital. To adjust for variations in the quality of care between hospitals, we used the average mortality rates per year in each hospital. Therefore, the second output represents 1 minus the average hospital mortality rate per year ( 1 - MORTALITY). This could lead to the concern that case mix might vary systematically across the hospitals in our sample, which would be problematic because hospitals with a more complex case mix should receive lower efficiency scores in the first stage of our analysis. To help address this potential issue, we included casemix measures in our regression analysis as control variables (see further details in section 3.2). A descriptive overview of the inputs and outputs used for our DEA model is given in Table 1.

A correlation analysis (Appendix 1) shows that our multiple inputs are positively correlated with our 
output set. This is an important prerequisite for applying DEA. In addition, subsets of inputs and outputs are often correlated. In our study especially the input variables are highly correlated. This might suggest that a limited number of inputs might adequately represent the selected input set in our efficiency assessment. However, several authors (e.g., Dyson, Allen, Camanho, Podinovski, Sarrico, and Shale 2001; Jacobs, Smith, and Street 2006) argue that omission of a highly correlated variable can lead to significant changes in the efficiency estimates. They emphasize that correlation is an aggregate measure of the closeness of two sets of observed data. Therefore, variations of the input levels of individual hospitals may have little effect on the correlation, but significant effect on the measured efficiency. It may also give evidence for a possible production technology that is common among all decision-making units. In addition Dyson, Allen, Camanho, Podinovski, Sarrico, and Shale (2001) argue that the omission of variables in order to increase discrimination is less relevant for large data samples. Thus, we used all input variables for our DEA model.

Table 1: Variable definitions and descriptive statistics for first-stage analysis*

\begin{tabular}{|c|c|c|c|}
\hline Variable name & Definition & Mean & SD \\
\hline CLIN & $\begin{array}{l}\text { Number of clinical } \\
\text { staff in FTE }\end{array}$ & 78.17 & 106.54 \\
\hline PUBLIC & & 112.7 & 182.8 \\
\hline PRIVATE-NP & & 52.4 & 42.1 \\
\hline PRIVATE-FP & & $47 \cdot 9$ & 63.1 \\
\hline NURS & $\begin{array}{l}\text { Number of nursing } \\
\text { staff in FTE }\end{array}$ & 225.8 & $225 \cdot 3$ \\
\hline PUBLIC & & 296.6 & 353.4 \\
\hline PRIVATE-NP & & 181.3 & 123.6 \\
\hline PRIVATE-FP & & 137.5 & 132.3 \\
\hline MEDTECH & $\begin{array}{l}\text { Number of medical } \\
\text { technicians in FTE }\end{array}$ & 163.3 & 231.3 \\
\hline PUBLIC & & 240.9 & $415 \cdot 9$ \\
\hline PRIVATE-NP & & 106.5 & 80.7 \\
\hline PRIVATE-FP & & 92.0 & 110.0 \\
\hline ADMIN & $\begin{array}{l}\text { Number of adminis- } \\
\text { trative staff in FTE }\end{array}$ & 43.1 & 56.0 \\
\hline PUBLIC & & 60.0 & 100.8 \\
\hline PRIVATE-NP & & 31.1 & 19.9 \\
\hline PRIVATE-FP & & 26.4 & 24.8 \\
\hline
\end{tabular}

\begin{tabular}{|c|c|c|c|}
\hline OTHER & $\begin{array}{l}\text { Number of other } \\
\text { staff in FTE }\end{array}$ & 87.4 & 106.7 \\
\hline PUBLIC & & 127.7 & 184.9 \\
\hline PRIVATE-NP & & 60.0 & $45 \cdot 9$ \\
\hline PRIVATE-FP & & 44.1 & $45 \cdot 9$ \\
\hline SUPPLIES & $\begin{array}{l}\text { Amount of supplies } \\
\text { in million euros }\end{array}$ & 16.1 & 23.0 \\
\hline PUBLIC & & 22.8 & 38.8 \\
\hline PRIVATE-NP & & 10.6 & 9.5 \\
\hline PRIVATE-FP & & 11.5 & 14.5 \\
\hline INPATIENT & $\begin{array}{l}\text { Number of treated } \\
\text { cases }\end{array}$ & 10,852 & 9,912 \\
\hline PUBLIC & & 13,941 & 14,731 \\
\hline PRIVATE-NP & & 8,809 & 5,839 \\
\hline PRIVATE-FP & & 7,340 & 7,180 \\
\hline 1-MORTALITY & $\begin{array}{l}1 \text { minus the average } \\
\text { mortality rates per } \\
\text { year }\end{array}$ & 0.974 & 0.015 \\
\hline PUBLIC & & 0.973 & 0.011 \\
\hline PRIVATE-NP & & 0.974 & 0.018 \\
\hline PRIVATE-FP & & 0.977 & 0.020 \\
\hline DEA I** & $\begin{array}{l}\text { Average DEA effi- } \\
\text { ciency scores }\end{array}$ & 0.634 & 0.138 \\
\hline PUBLIC & & 0.649 & 0.130 \\
\hline PRIVATE-NP & & 0.623 & 0.136 \\
\hline PRIVATE-FP & & 0.619 & 0.170 \\
\hline DEA II ${ }^{* *}$ & $\begin{array}{l}\text { Average DEA effi- } \\
\text { ciency scores }\end{array}$ & 0.636 & 0.137 \\
\hline PUBLIC & & 0.654 & 0.128 \\
\hline PRIVATE-NP & & 0.623 & 0.136 \\
\hline PRIVATE-FP & & 0.619 & 0.17 \\
\hline DEA III ${ }^{* *}$ & $\begin{array}{l}\text { Average DEA effi- } \\
\text { ciency scores }\end{array}$ & 0.662 & 0.133 \\
\hline PUBLIC & & 0.674 & 0.125 \\
\hline PRIVATE-NP & & 0.652 & 0.132 \\
\hline PRIVATE-FP & & 0.658 & 0.158 \\
\hline
\end{tabular}

${ }^{*}$ Pooled sample including university hospitals and hospitals with beds $\geq 50$.

${ }^{* *} D E A$ models are specified in table 2.

Three model specifications served as a sensitivity analysis to test whether the efficiency scores and ranks remained stable when a specific variable (quality of care as second output) or specific providers (university hospitals) were removed or added. Efficiency models I and II both used INPATIENT as the only output variable, whereas university hospitals were removed in the second analysis. The third 
DEA model reflects quality of care using 1-MORTALITY as a second output; here, too, university hospitals were excluded. The specifications are summarized in Table 2.

Table 2: Specification of DEA models*

\begin{tabular}{lll}
\hline Models & Trimming & Output \\
\hline DEA I & $\begin{array}{l}\text { With university hospi- } \\
\text { tals }\end{array}$ & INPATIENT \\
\hline DEA II & $\begin{array}{l}\text { Without university } \\
\text { hospitals }\end{array}$ & INPATIENT \\
\hline DEA III & $\begin{array}{l}\text { Without university } \\
\text { hospitals }\end{array}$ & $\begin{array}{l}\text { INPATIENT \& } \\
\text { 1-MORTALITY }\end{array}$ \\
\hline
\end{tabular}

"Models are estimated per year (2002-2006)

\subsection{Second Stage: Truncated Linear Regression Model}

An important assumption of our study was that environmental and organizational factors may influence the relative efficiency of hospitals in addition to ownership. By considering the impact of covariates reflecting environmental and organizational factors on hospital efficiency we believe to provide a better explanation of the variation of efficiency and more robust results about the effects of ownership than previous studies that did not control for these effects. We therefore used the DEA efficiency scores obtained in the first stage of our analysis as dependent variable in a truncated linear regression model, which became the favored approach owing to the censored distribution of the DEA-based relative efficiency estimates (Simar and Wilson 2007). This model is appropriate for these data, as these are bounded at both ends of the o-1 distribution (Jacobs, Smith, and Street 2006). However, this approach has been found to result in inconsistent estimates unless the DEA efficiency scores are corrected by a bootstrapping procedure. The procedure applied in the present study follows the bootstrap approach developed by Simar and Wilson (1998, 2000). For our study, the bias-corrected scores were derived from 250 bootstrap iterations, which allowed us to estimate a robust regression model as the second-stage analysis (Simar and Wilson 2007). Based on our theoretical framework, the following empirical model was used in the analysis. In the input-oriented case, the variable returns to scale variant of the BCC (Banker, Charnes, and Cooper) model can be formulated as a linear programming problem as shown below (Banker, Charnes, and Cooper 1984). Let $\theta_{i}, i=1, \ldots, n$, be the hospital's efficiency where $n$ represents the number of observations (i.e. the number of hospitals). Matrix $\mathbf{X} \in \mathbb{R}^{k x n}$ refers to $k$ observed inputs of $n$ compared hospitals and matrix $\mathbf{Y} \in \mathbb{R}^{r \times n}$ refers to $r$ observed outputs of the compared hospitals. Vectors $\mathbf{x}_{i} \in \mathbb{R}^{k}$ and $\mathbf{y}_{i} \in \mathbb{R}^{k}$ present the inputs and outputs of unit $i$, i.e. the $i$ th columns of matrix $\mathbf{X}$ and $\mathbf{Y}$ respectively. Furthermore, $\mathbf{1}$ refers to a column vector of ones with a suitable dimension.

The DEA efficiency score, which is the reciprocal of the inefficiency, $\theta_{i}$ can be obtained by solving the following $\mathrm{BCC}$ linear programming model:

$$
\begin{array}{ll}
\vartheta_{i}= & \operatorname{Max} \theta_{i}, \\
\text { s.t. } & \mathbf{Y} \lambda-\mathbf{y}_{0} \geq 0, \\
& -\mathbf{X} \lambda+\theta_{i} \mathbf{x}_{0} \geq 0, \\
- & \mathbf{X} \lambda+\theta_{i} \mathbf{x}_{0} \geq 0, \\
& 1^{\mathrm{T}} \lambda=1, \lambda \geq 0 .
\end{array}
$$

In the second step, we used the following model specifications for our regression analysis. Let $\mathbf{z}_{i}$ be each corresponding vector of covariates (i.e. types of ownership, hospital characteristics, environmental characteristics, and patient heterogeneity). According to Simar and Wilson (2007), we applied a truncated linear regression to model hospital's efficiency. Therefore, we assumed $\theta_{i}$ as being distributed based upon a set of $\mathrm{m} \geq \mathrm{n}$ normally distributed random variables, $\vartheta_{j}, j=1, \ldots, m$ with

(6) $\vartheta_{j}=\tilde{\mathbf{Z}}_{j} \beta+\varepsilon_{j}$,

where $\tilde{\mathbf{Z}}_{j}$ refers to a vector of covariates, $\beta$ represents a parameter vector, and $\varepsilon_{j}$ is a normally distributed error term (i.e. $\left.\varepsilon_{j} \sim \mathrm{N}\left(0, \sigma_{\varepsilon}^{2}\right)\right)$. On this basis $\theta_{1}, \ldots, \theta_{n}$ is defined as the truncated set of $\vartheta_{1}, \ldots, \vartheta_{m}$ with $\vartheta_{j} \leq 1$, and $\mathbf{Z}_{i}=\tilde{\mathbf{Z}}_{j}$ for $\theta_{i}=\vartheta_{j}$.

We applied linear regression analysis to assess whether different types of ownership (PUBLIC, PRIVATE-FP, and PRIVATE-NP) led to differences in efficiency; we also considered a number of control variables. The use of control variables is of particular importance in the healthcare context because there are usually certain structural or regulatory 
determinants of hospital efficiency that a hospital cannot influence.

Heterogeneity in hospital characteristics was covered by the following variables. The first of these was the number of licensed and staffed beds (BEDS), an approach taken in previous studies to control for hospital size (Carey and Burgess 1999; Dudley, Johansen, Brand, Rennie, and Milstein 2000; Harrison, Coppola, and Wakefield 2004). In the context of strict hospital planning in Germany, the number of beds per hospital can be seen, at least in the medium term, as an exogenous factor outside of hospital management's control (Busse and Riesberg 2004). To account for higher resource consumption due to differences in teaching activities, we included a variable (TEACH) for the training of non-medical staff. These activities are represented by the ratio of trainee positions to the sum of all non-medical personnel. Another important point is that hospitals may hire out beds to self-employed ambulatory physicians (e.g., for ambulatory surgery). The estimated DEA efficiency scores in the first stage of our analysis were higher for these hospitals because the referring cases were counted as hospital output, whereas the corresponding resource use in terms of physicians was not considered on the input side. To control for this fact, we considered the proportion of all hospital beds that had been hired (HIRED BEDS) as variable in the regression models. The dummy variable "ambulatory care" (AMBULATORY) is related to missing data from the first stage of our analysis, which only considers the inputs for the production of ambulatory care, whereas the outputs of the ambulatory activities (e.g., ambulatory visits) were not captured in our data set. Because of the ongoing trend towards privatization in Germany, one could argue that a large number of the existing private for-profit hospitals were recently converted from public and non-profit ownership status and that most of these hospitals represent inefficient units. Therefore, we included a dummy variable (CONVERSION) to account for public and non-profit hospitals that were privatized during the study period $(n=68)$.

The set of explanatory variables representing the different environmental characteristics were as follows. The most important regressor is the Hirschman-Herfindahl index (HHI), which measures competitive pressure in a hospital's market, a standard economic measure of industry concentration. The market area was defined as the county in which a hospital was located, which is a frequently used definition in hospital studies (Chang, Chang, Das, and Li 2004; Rosko 1999, 2001, 2004; Rosko and Chilingerian 1999; Chirikos and Sear 1994). Although there has been some controversy about the appropriate definition of a hospital's market area, Garnick, Luft, Robinson, and Tetreault (1987) reported that, for the purpose of measuring competitive activity, it made little difference whether a hospital's market was defined as a county or as a radius. The HHI is obtained by squaring the regional market share of a hospital (reflected by the distribution of treated cases), and then summing the market shares of admissions for all of the hospitals in the county. The higher the HHI, the more concentrated the regional market. We used HHI to measure the effects through the changes over time in hospitals' competitive environment. This specification allowed us to differentiate between the effects of ownership and the effects of changes in market structure resulting from recent healthcare reforms. Furthermore, variations may also result from the fact that hospitals located in eastern or western Germany are different in terms of their infrastructure. After German reunification in 1990, hospitals in eastern Germany received comparably higher subsidies from the federal government to upgrade their infrastructure (Busse and Riesberg 2004). Thus, we defined being located in eastern Germany (including all of Berlin) as a dummy variable (EAST).

Because resource consumption can vary substantially between patients, we also included 26 variables to control for variations associated with casemix complexity. We used patient-level information on diagnoses, procedures, and age to control for patient heterogeneity. To control for case-mix complexity, we compiled a comprehensive list of comorbidities that have been found in other studies to affect mortality and resource use. In doing so, we relied on the Charlson Comorbidity Index (Sundararajan, Henderson, Perry, Muggivan, Quan, and Ghali 2004). Thus, the full set of case-mix measures are included in all of the regression models deployed in our second-stage analysis. Another common approach would be to use the case-mix index whose weight reflects the relative costliness of DRGs. Due to data privacy issues, we were not permitted to match the referring data. However, Carey (2000, 2002) reported that individual-level measures represent a vast improvement over aggregate case-mix measures and that the DRG case-mix in- 
dex is therefore a relatively weak measure of sickness to control for patient heterogeneity.

To check the robustness of our estimates, we performed three regression models using the DEA efficiency scores from three different DEA specifica- tions as dependent variables (see Table 1). Table 3 provides the definitions of variables for our secondstage analysis and the overall descriptive statistics of our sample with respect to the dependent and independent measures.

Table 3: Variable definitions and descriptive statistics for second-stage analysis ${ }^{*}$

\begin{tabular}{|c|c|c|c|}
\hline Variable name & Definition & Mean & SD \\
\hline HHI & Index for concentration of hospital cases per county & 0.345 & 0.219 \\
\hline PUBLIC & & 0.402 & 0.247 \\
\hline PRIVATE-NP & & 0.283 & 0.187 \\
\hline PRIVATE-FP & & 0.355 & 0.229 \\
\hline BEDS & Number of beds per hospital & 330.3 & 279.3 \\
\hline PUBLIC & & 417.7 & 418.6 \\
\hline PRIVATE-NP & & 272.4 & 161.7 \\
\hline PRIVATE-FP & & 231.2 & 199.8 \\
\hline EAST & Dummy variable for hospitals located in the eastern part of Germany & 0.183 & 0.379 \\
\hline PUBLIC & & 0.178 & 0.382 \\
\hline PRIVATE-NP & & 0.139 & 0.346 \\
\hline PRIVATE-FP & & 0.332 & 0.471 \\
\hline AMBULATORY & Dummy variable for hospitals that provide ambulatory care & 0.783 & 0.395 \\
\hline PUBLIC & & 0.856 & 0.351 \\
\hline PRIVATE-NP & & 0.791 & 0.406 \\
\hline PRIVATE-FP & & 0.525 & 0.500 \\
\hline HIRED BEDS & Ratio of hired out beds to all beds & 0.068 & 0.141 \\
\hline PUBLIC & & 0.065 & 0.115 \\
\hline PRIVATE-NP & & 0.063 & 0.134 \\
\hline PRIVATE-FP & & 0.091 & 0.243 \\
\hline TEACH & Ratio of apprenticeship training positions & 0.269 & 0.426 \\
\hline PUBLIC & & 0.302 & 0.518 \\
\hline PRIVATE-NP & & 0.274 & 0.355 \\
\hline PRIVATE-FP & & 0.150 & 0.355 \\
\hline CONVERSION & $\begin{array}{l}\text { Dummy variable for hospitals that were privatized during study } \\
\text { period }\end{array}$ & 68 & \\
\hline PUBLIC & & 50 & \\
\hline PRIVATE-NP & & 18 & \\
\hline
\end{tabular}

*Pooled sample including university hospitals and hospitals with beds $\geq 50$. 


\section{$4 \quad$ Findings and discussion}

The regression results for the three regression models are summarized in Table 4. A correlation analysis of our explanatory variables suggested that multi-collinearity was not an issue in our study (see variance inflation factors in Appendix 3). The coefficients can be interpreted as marginal effects, and private for-profit hospitals served as a reference category. Throughout the models, ownership was coded as a dummy variable. The regression results for all three models showed that public hospitals operate at a significantly higher level of efficiency than their counterparts. According to this result our first hypothesis has to be rejected. However, the impact of public ownership was lower for the first model, which included university hospitals (effect of $1.9 \%$; $\mathrm{P} \leq 0.01$ ), than it was for the second model (effect of $2.3 \%$; $\mathrm{P} \leq 0.001$ ). University hospitals were clearly associated with lower efficiency in our first model. This can be explained by the fact that university hospitals produce multiple outputs (i.e. a combination of patient care, education, and research) (Schreyögg and Reitzenstein 2008); as a result, their production process is not adequately captured by our DEA models.

In addition to the different model variations performed for sensitivity purposes we checked the robustness of our findings in several ways. To begin with, we re-estimated our first- and second-stage models with different windows for hospital sizes at the lower end of the sample. We performed four different models including all hospitals above 30 beds, above 50 beds, above 70 beds, and above 100 beds. Efficiency differences between private hospitals and the two other hospital types tended to be slightly larger when 30 beds were used as the lowest hospital size included in our study while the results hardly changed when sizes of 70 beds or 100 beds were used as the minimum number of beds per hospital instead of 50 beds. Second, we run the second-stage models modifying the number of periods used in our regression (2 years, 3 years, 4 years, and 5 years). The modifications had very little effect on the coefficients representing different ownership types (see Appendix 4 and 5 for regression results).

Looking at the development of efficiency scores over time it turns out that efficiency of all ownership types slightly increases over the years to a similar extent. Finally, in our third DEA model we used 1 minus the average hospital mortality rate per year, which represents an index variable. Syrjänen (2004)

Table 4: Regression results for each model

\begin{tabular}{|c|c|c|c|}
\hline $\begin{array}{l}\text { Independent } \\
\text { variables }\end{array}$ & DEA I & DEA II & DEA III \\
\hline & \multicolumn{3}{|l|}{ Coefficients } \\
\hline PUBLIC & $0.019^{* * *}$ & $0.023^{* * *}$ & $0.018^{* * *}$ \\
\hline PRIVATE-NP & 0.009 & 0.010 & 0.006 \\
\hline PRIVATE-FP & \multicolumn{3}{|c|}{ Served as reference category } \\
\hline HHI & $0.086^{* * *}$ & $0.085^{* * * *}$ & $0.069^{* * * *}$ \\
\hline BEDS (in 1,ooo) & $0.061^{* * * *}$ & $0.085^{* * * *}$ & $0.064^{* * * *}$ \\
\hline EAST & $0.012^{*}$ & $0.012^{*}$ & $0.024^{* * *}$ \\
\hline AMBULATORY & $-0.018^{* * * *}$ & $-0.019^{* * * *}$ & $-0.028^{* * * *}$ \\
\hline HIRED BEDS & $0.049^{*}$ & $0.054^{* *}$ & $0.038^{*}$ \\
\hline TEACH & 0.004 & 0.003 & 0.001 \\
\hline CONVERSION & -0.002 & 0.002 & 0.009 \\
\hline $\begin{array}{l}26 \text { Case-mix va- } \\
\text { riables }\end{array}$ & Included & Included & Included \\
\hline
\end{tabular}

found that mixing index and volume measures in DEA may lead to biased results for the most commonly used constant returns to scale variant of the BM model (Banker and Moorey model) and the CCR model (Charnes, Cooper, and Rhodes model). However, this problem does not apply in our context as we used a variable returns to scale variant of the BCC model. Thus, in our case the use of an index variable leads to robust results (Hollingsworth and Smith 2003; Syrjänen 2004).

According to our second hypothesis a trade-off between efficiency and quality of care would lead to smaller efficiency differences between ownership types. Compared to DEA models I and II the relative efficiency of PUBLIC hospitals decreased in the DEA III model when quality was considered as an additional output. Thus, we indeed observed a trade-off between efficiency and quality of care supporting hypothesis 2. However, the regression analysis that used quality-adjusted DEA efficiency scores as the dependent variable (i.e. DEA III) revealed significantly higher efficiency for public ownership compared to other ownership types.

Our general finding that public hospitals perform better than hospitals with other forms of ownership is consistent with the results of several earlier stu- 
dies which, however, as mentioned earlier, have certain methodological limitations. Among the control variables, market concentration (HHI) and hospital size (BEDS) were important exogenous market effects, and the regression results revealed a significant positive association with efficiency in all three models $(\mathrm{P} \leq 0.001)$. In empirical studies on hospital efficiency, the variable "beds per hospital" is often used as a proxy for hospital size. However, as Breyer (1987) indicated, the variable also contains information on capital inputs. If beds are interpreted as a measure of size, we can conclude that larger hospitals perform significantly better. However, studies on the relationship between hospital costs and hospital size measured in terms of beds have generally identified a U-curve, because marginal costs tend to decline with increased size and then rise again, as indicated by a negative sign for the variable "squared beds per hospital" in the regression (Carr and Feldstein 1967). In our regression, the variable "squared beds per hospital" and also the variable "cubed beds", which would imply a cubic relation, were not significant. Thus, our study shows that, in contrast to the evident relationship between costs and hospital size, the relationship between efficiency and hospital size is linear. In this context, it is important to emphasize that this finding is not biased by our scale assumptions. In our DEA model specification we used variable returns to scale because constant returns to scale are assumed to represent a hospital planning view or a governmental view (Steinmann, Dittrich, Karmann, and Zweifel 2004).

In their review of the literature, Scherer and Ross (1990) and Button and Weyman-Jones (1992) found that the degree of competitiveness in a firm's market was a potential source of lower efficiency. Classical economic theory predicts that organizations in monopolistic or oligopolistic markets restrict output and have higher average costs than competitive organizations. In our study, market competition was measured using the HirschmanHerfindahl index, which is defined over a range between zero and one such that increases in HHI correspond to decreases in hospital competition. Therefore, the positive coefficient lends support to the notion that a hospital's behavior is highly affected by competition in the hospital sector, though in a direction that is inverse to that seen in markets for most other goods and services. In the German context, this finding is also related to the strict regu- lations in place regarding hospital planning. Competition between hospitals in Germany does not occur primarily in terms of individual patients, but with regard to the optimal fit of demand and supply in terms of hospital infrastructure (e.g., specialties, departments, number of beds). Our findings indicate that hospitals operating in monopolistic or oligopolistic markets are more likely to agree with the hospital planning authorities on a hospital infrastructure that enables a convergence of demand and supply in the referring county. Overcapacities in urban areas result in greater competitive pressure (i.e. cutthroat competition), whereas counties with lower competitive pressure are likely to be more rural. As a regulatory instrument, hospital planning is supposed to lead to optimal hospital infrastructure and efficiency. Our results indicate, however, that this is a questionable assumption that needs to be addressed by further research. However, Rosko (1999, 2001, 2004) and Rosko and Chilingerian (1999) found efficiency in the US hospital sector to be negatively related to market competition, a finding similar to that in our own study.

Figure 1 shows the DEA efficiency scores and quality-adjusted DEA efficiency scores as predicted values (from the DEA II and DEA III models) versus hospital size and market concentration for the different types of ownership. Generally, there was a linear relationship between hospital size and DEA efficiency scores and quality-adjusted DEA efficiency scores.

Taking a closer look at the three different curves, it becomes clear that public hospitals outperformed their private for-profit and non-profit counterparts up to a size of approximately 1,00o beds. From 1,00o beds onwards, the private for-profit hospitals operated with greater efficiency, which also holds after taking quality into account. However, most private for-profit providers in Germany operate within a size range of 50 to 800 beds. Indeed, of the hospitals in our sample that had more than 1,000 beds, only 15 were private for-profit hospitals, whereas 119 were public hospitals.

Generally, the relationship between market concentration and efficiency / quality-adjusted efficiency was also linear, although the public hospitals in our sample operated at a substantially higher level of efficiency in all of the various settings of competitive pressure (Figure 1).

Private for-profit hospitals show a comparably low level of performance in very competitive markets. 
Figure 1: DEA efficiency scores and quality-adjusted DEA efficiency scores as predicted values versus hospital size and market concentration

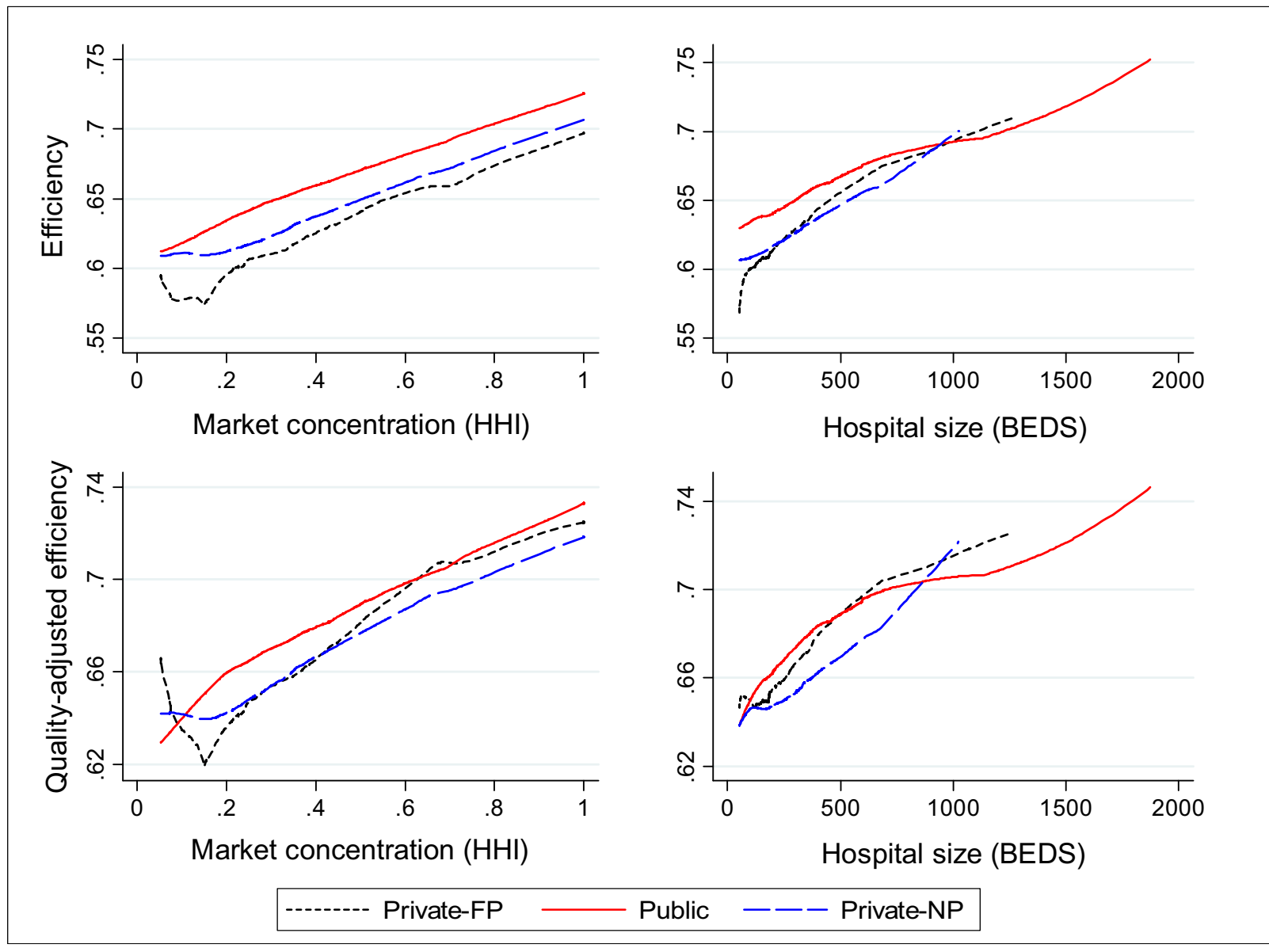

Here, it is important to recognize that private forprofit and non-profit hospitals operate primarily in urban and other more competitive areas, whereas public hospitals operate both in urban and noncompetitive regions (Figure 2).

Furthermore, it is striking that in Figure 1, particular in relation to market concentration, the efficiency curves and quality-adjusted efficiency curves of private for-profit hospitals are descending first and then raise linear. This descending curve can be explained by an interaction effect between private ownership, hospital size and market concentration. Those private for-profit hospitals operating in more competitive regions have comparably smaller entities in these regions than hospitals of other ownership types. Therefore, the hospitals represented by the descending curve combine three characteristics that are associated with lower efficiency. If private for-profit hospitals operate in more concentrated regions the size of the entities approaches that of other ownership types and thus differences between efficiency scores of different ownership types become smaller.

As expected, other control variables also had a significant impact on efficiency (Table 4); the case-mix variables, in particular, had a major impact in this regard (see Appendix 2 for the full model specification). Our set of case-mix variables accounted for approximately two-thirds of the explained variance in the three full models (based on ordinary least square estimates), which indicates the importance of adjusting for patient heterogeneity. As expected, the operational efficiency of hospitals located in eastern Germany (EAST) was significantly greater than that of their western counterparts. This can be explained by the large investments made to modernize hospital infrastructure in eastern Germany after the German reunification in 1990. In addition, hiring out a larger share of beds to ambulatory physicians was associated with higher efficiency 
Figure 2: Histogram with hospital density versus market concentration

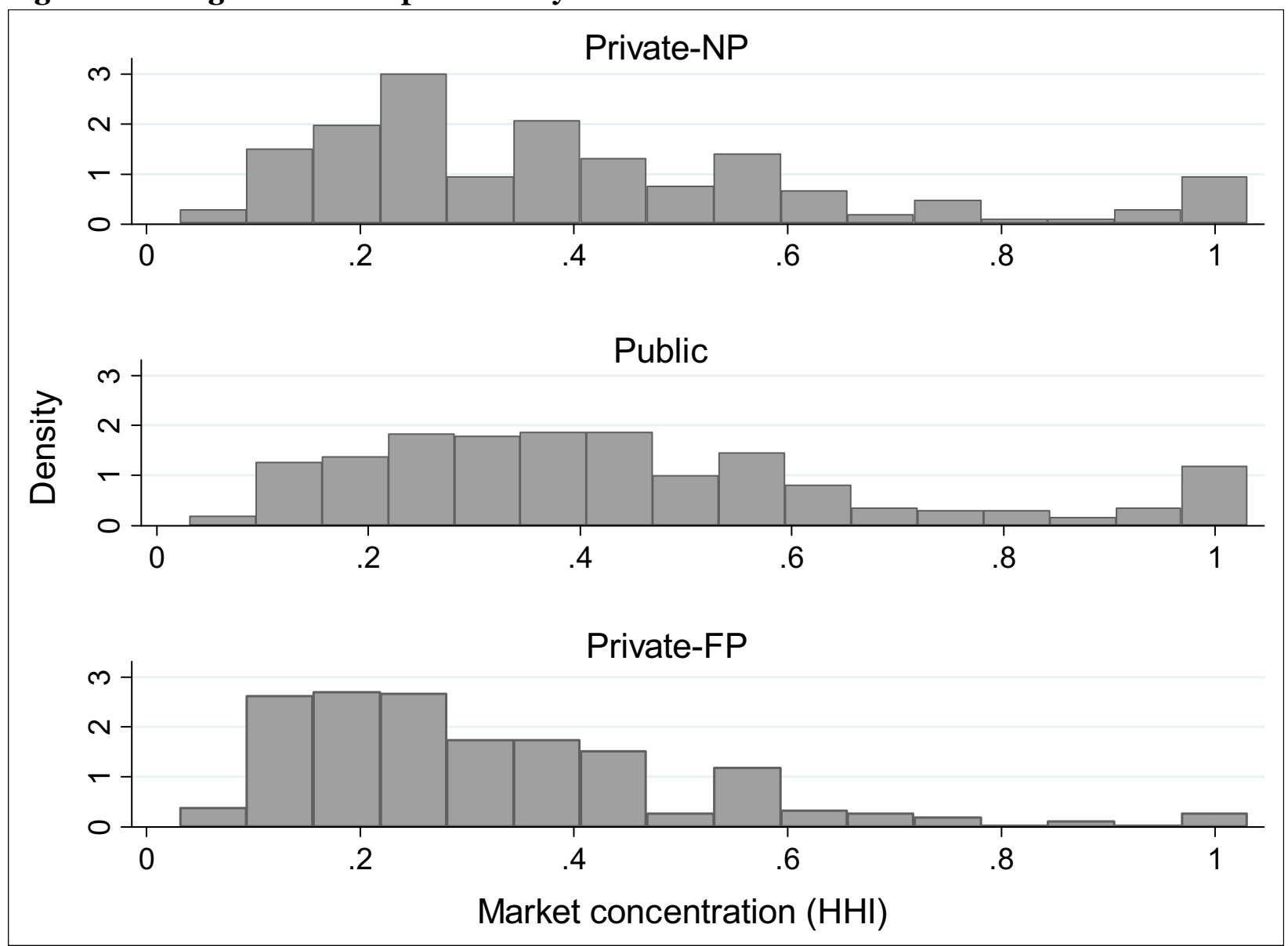

(HIRED BEDS), and the existence of ambulatory care activities was associated with lower efficiency (AMBULATORY).

Several of our findings are likely to be thoughtprovoking, because they are counter-intuitive and are not in line with the arguments put forward by authors in the field of agency theory and propertyrights theory, as well as public choice theory. This may be explained by a number of specific characteristics of the hospital market in Germany. Our results show that for-profit status was associated with lower efficiency. However, for-profit hospitals may have found a different way to maximize their profits (i.e. financial surplus) than hospitals with other forms of ownership. Indeed, they may seek to maximize their profits by maximizing revenues instead of minimizing inputs at a given output, which was defined as a measure of efficiency in our study. Wörz (2008) supports this view, having found that private forprofit hospitals (and especially hospital chains) were able to generate significantly higher revenues per case on the average than hospitals with other forms of ownership. This study of a large German hospital sample $(n=1,614)$ with data from 2004 reflects the pre-DRG era in Germany, during which prices could be negotiated. However, even after the introduction of DRGs, today there are still a substantial number of additional reimbursement components being paid on the top of DRGs that can be negotiated at the hospital level (e.g., certain expensive drugs). Indeed, these additional components account for approximately $20 \%$ of total reimbursements for non-psychiatric inpatient care (Schreyögg, Tiemann, and Busse 2006). Shen, Eggleston, Lau, and Schmid (2007) found comparable results for the US hospital sector, concluding that the mission of private for-profit hospitals puts greater emphasis on earning profits (i.e. higher revenues per case due to higher prices) compared to public hospitals, which focus primarily on efficiency.

Private for-profit providers are more efficient among the very large hospitals with more than 
1,000 beds. This finding is in line with the theories mentioned above. Private for-profit providers have stronger incentive schemes and control mechanisms, which are of crucial importance for the management of larger organizations (Bishop and Thompson 1992).

Our results also indicate that private for-profit hospitals provide a higher quality of care compared to other types of ownership. As mentioned above, theoretical approaches assume that information asymmetries exist in the hospital market and thus particularly for-profit hospitals have the incentive (i.e. profit-seeking) to increase productive efficiency at the expense of quality of care. However, in the German hospital sector information asymmetry has decreased over the last decade due to a variety of healthcare reforms aiming at quality assurance (e.g., mandatory publication of quality reports). Furthermore, the mentioned theoretical approaches do not account for the strategic importance of quality of care in markets with substantial overcapacities (i.e. cutthroat competition). There is evidence that private for-profit hospitals (and especially private forprofit hospital chains) operating in more competitive regions have improved their quality management and hospital outcomes in order to attract patients (Busse, Nimptsch, and Mansky 2009).

Our study has a number of strengths plus adds value compared to previous approaches. First, it applies a more refined approach to investigate the effects of ownership on hospital efficiency in Germany. To our knowledge, it is the first study to examine the relationship between ownership status and efficiency using a panel data approach based on bootstrapped DEA efficiency scores. Second, our panel $(n=1,046)$ is large and covers the majority of all German acutecare hospitals over five years, allowing us to control for serial correlation and providing greater statistical power than in previous studies leading to more robust estimates. Third, the sample is rich, containing information at the patient and hospital levels. Within our two step approach, this allowed us to control appropriately for case-mix and other environmental and organizational characteristics, and is likely to have yielded more consistent results. Fourth, this is the first ownership study in the hospital sector to incorporate quality measures as outputs in DEA models.

Our study also has several important limitations. First, additional inputs and outputs (e.g., ambulatory cases as an additional output, or capital as an additional input) would have helped us capture more of the resources required in and all of the output produced from the hospital production process. Considering the number of outpatient cases in addition to inpatient cases is generally recommended in order to measure patient care output (Jacobs, Smith, and Street 2006). We intended to include a proxy for hospital outpatient activities (e.g., outpatient surgery). However, data inconsistencies and measurement errors did not allow us to use this information for further analysis.

Including other explanatory factors in addition to environmental and organizational characteristics might have provided a better explanation of variation in our estimates, thus potentially affecting our interpretation of the relationship between ownership and efficiency. Another limitation may be that this study uses mortality as the only indicator for quality of care. Moreover, we were not able to take account of hospitals that were privatized during the 3 years prior to our study period. Nevertheless, our study results gave no indication that the hospitals privatized during our study period were primarily inefficient units. Finally, our study employed only DEA, although it would have been possible to use SFA in addition to DEA. SFA was not included in the analysis, however, because it relies on assumptions about the functional form of the production or cost frontier that we aimed to avoid. Further, Linna (1998) found that both methods yielded comparable results for individual efficiency.

\section{$5 \quad$ Summary and outlook}

In this paper, we investigated the effects of ownership on hospital efficiency in Germany. Our findings show that public ownership was associated with significantly higher efficiency than other forms of ownership; private for-profit ownership, in particular, was associated with lower efficiency. These key findings remained unchanged after conducting a number of sensitivity checks. Our results suggest that private for-profit hospitals place greater emphasis on earning profits (i.e. higher revenues per case due to higher prices), whereas public hospitals, because of resource constraints, focus primarily on input efficiency. We also found a significant positive association between hospital size and efficiency, and that competitive pressure had a significant negative impact on hospital efficiency. From a strategic management point of view, private for-profit hospitals 
may be well advised to change their acquisition strategy in terms of choice of hospital size and location. In addition, the ongoing trend towards privatization in Germany may not be an appropriate way to ensure the best use of the scarce resources in the hospital sector, because public hospitals use relatively fewer resources than private for-profit hospitals. Additional longitudinal studies are thus needed to measure and compare the efficiency of privatized hospitals. This could be a fruitful way to gain a better understanding of the consequences of ongoing privatization in the hospital sector.

\section{Acknowledgements}

The authors are grateful for the insightful comments by two anonymous BuR reviewers on previous versions of the paper. Furthermore, we would like to thank the Research Data Centre of the Statistical Offices of the Länder for providing the data for our analysis (No. 842-2008). Our research was supported within the Munich Center of Health Sciences (MC-Health) as part of LMUinnovativ.

Appendix 1: Correlation matrix for the input and output variables

\begin{tabular}{|c|c|c|c|c|c|c|c|c|}
\hline Variables & $\mathbf{1}$ & 2 & 3 & 4 & 5 & 6 & 7 & 8 \\
\hline 1 - CLIN & 1 & & & & & & & \\
\hline 2 - NURS & 0.936 & 1 & & & & & & \\
\hline 3 - MEDTECH & 0.971 & 0.915 & 1 & & & & & \\
\hline 4 - ADMIN & 0.950 & 0.893 & 0.940 & 1 & & & & \\
\hline 5 - OTHER & 0.870 & 0.890 & 0.872 & 0.874 & 1 & & & \\
\hline 6 - SUPPLIES & 0.960 & 0.909 & 0.951 & 0.907 & 0.835 & 1 & & \\
\hline 7 - INPATIENT & 0.911 & 0.948 & 0.856 & 0.841 & 0.821 & 0.862 & 1 & \\
\hline 8 - 1-MORTALITY & 0.084 & 0.067 & 0.088 & 0.073 & 0.074 & 0.093 & 0.075 & 1 \\
\hline
\end{tabular}

\section{Appendix 2: Correlation matrix for the organizational and environmental variables}

\begin{tabular}{|c|c|c|c|c|c|c|c|}
\hline Variables & $\mathbf{1}$ & 2 & 3 & 4 & 5 & 6 & 7 \\
\hline 1 - HHI & 1 & & & & & & \\
\hline 2 - BEDS & 0.106 & 1 & & & & & \\
\hline 3 - EAST & 0.359 & 0.101 & 1 & & & & \\
\hline 4 - AMBULATORY & 0.041 & 0.162 & -0.072 & 1 & & & \\
\hline 5 - HIRED BEDS & -0.041 & -0.197 & -0.168 & -0.081 & 1 & & \\
\hline 6 - TEACH & 0.001 & 0.134 & -0.060 & 0.018 & -0.077 & 1 & \\
\hline 7 - CONVERSION & 0.062 & 0.003 & 0.040 & -0.035 & -0.042 & 0.043 & 1 \\
\hline
\end{tabular}


BuR - Business Research

fficial Open Access Journal of VHB

Verband der Hochschullehrer fur Betriebswirtschaft e.V.

Volume 2 | Issue 2 | December 2009 | 115-145

Appendix 3: Regression results for each model - full model specification

\begin{tabular}{|c|c|c|c|c|c|c|c|c|c|c|c|c|c|}
\hline \multirow{2}{*}{$\begin{array}{l}\text { Independent vari- } \\
\text { ables }\end{array}$} & \multicolumn{4}{|c|}{ DEA I } & \multicolumn{5}{|c|}{ DEA II } & \multicolumn{4}{|c|}{ DEA III } \\
\hline & $\begin{array}{l}\text { Coeffi- } \\
\text { cients }\end{array}$ & $\begin{array}{l}\text { Standard } \\
\text { error }\end{array}$ & z-value & p-value & $\begin{array}{l}\text { Coeffi- } \\
\text { cients }\end{array}$ & $\begin{array}{l}\text { Standard } \\
\text { error }\end{array}$ & z-value & p-value & $\begin{array}{l}\text { Variance } \\
\text { inflation } \\
\text { factor }\end{array}$ & $\begin{array}{l}\text { Coeffi- } \\
\text { cients }\end{array}$ & $\begin{array}{l}\text { Standard } \\
\text { error }\end{array}$ & z-value & p-value \\
\hline \multicolumn{14}{|l|}{ Ownership } \\
\hline PUBLIC & 0.019 & 0.007 & 2.850 & 0.004 & 0.023 & 0.007 & $3 \cdot 380$ & 0.001 & & 0.018 & 0.007 & 2.720 & 0.007 \\
\hline PRIVATE-NP & 0.009 & 0.007 & 1.340 & 0.180 & 0.010 & 0.007 & 1.450 & 0.147 & & 0.006 & 0.006 & 0.890 & 0.376 \\
\hline PRIVATE-FP & \multicolumn{13}{|c|}{ served as reference category } \\
\hline
\end{tabular}

\begin{tabular}{lllllllllllllll}
\hline $\begin{array}{l}\text { Organizational and } \\
\text { environmental vari- } \\
\text { ables }\end{array}$ & & & & & & & & & & & & & & \\
\hline HHI & 0.086 & 0.010 & 8.970 & 0.000 & 0.085 & 0.010 & 8.860 & 0.000 & 1.29 & 0.069 & 0.009 & 7.420 & 0.000 \\
\hline BEDS (in thousands) & 0.061 & 0.010 & 6.380 & 0.000 & 0.085 & 0.011 & 8.040 & 0.000 & 1.62 & 0.064 & 0.010 & 6.500 & 0.000 \\
\hline EAST & 0.012 & 0.006 & 2.020 & 0.043 & 0.012 & 0.006 & 2.060 & 0.040 & 1.34 & 0.024 & 0.006 & 4.220 & 0.000 \\
\hline AMBULATORY & -0.018 & 0.005 & -3.480 & 0.001 & -0.019 & 0.005 & -3.750 & 0.000 & 1.15 & -0.028 & 0.005 & -5.690 & 0.000 \\
\hline HIRED BEDS & 0.049 & 0.017 & 2.950 & 0.003 & 0.054 & 0.016 & 3.250 & 0.001 & 1.12 & 0.038 & 0.016 & 2.380 & 0.017 \\
\hline TEACH & 0.004 & 0.005 & 0.940 & 0.347 & 0.003 & 0.005 & 0.750 & 0.454 & 1.15 & 0.001 & 0.005 & 0.190 & 0.853 \\
\hline CONVERSION & -0.002 & 0.009 & -0.180 & 0.857 & 0.002 & 0.009 & 0.180 & 0.859 & 1.12 & 0.009 & 0.009 & 0.950 & 0.344 \\
\hline
\end{tabular}


Appendix 3 continued: Regression results for each model - full model specification

\begin{tabular}{|c|c|c|c|c|c|c|c|c|c|c|c|c|c|}
\hline $\begin{array}{l}\text { Independent vari- } \\
\text { ables }\end{array}$ & DEA I & & & & DEA II & & & & & DEA I & & & \\
\hline & $\begin{array}{l}\text { Coeffi- } \\
\text { cients }\end{array}$ & $\begin{array}{l}\text { Standard } \\
\text { error }\end{array}$ & z-value & p-value & $\begin{array}{l}\text { Coeff- } \\
\text { cients }\end{array}$ & $\begin{array}{l}\text { Standard } \\
\text { error }\end{array}$ & z-value & p-value & $\begin{array}{l}\text { Variance } \\
\text { inflation } \\
\text { factor }\end{array}$ & $\begin{array}{l}\text { Coeffi- } \\
\text { cients }\end{array}$ & $\begin{array}{l}\text { Standard } \\
\text { error }\end{array}$ & z-value & $p$-value \\
\hline Case-mix variables & & & & & & & & & & & & & \\
\hline $\begin{array}{l}\text { AVAILAB. PET } \\
\text { (yes/no) }\end{array}$ & -0.046 & 0.012 & -4.020 & 0.000 & 0.008 & 0.014 & 0.530 & 0.599 & 1.08 & 0.010 & 0.014 & 0.730 & 0.466 \\
\hline $\begin{array}{l}\text { AVAILAB. CARD. } \\
\text { CATH. LAB. } \\
\text { (yes/no) }\end{array}$ & 0.027 & 0.006 & $4 \cdot 370$ & 0.000 & 0.024 & 0.006 & 3.820 & 0.000 & 1.68 & 0.020 & 0.006 & $3 \cdot 320$ & 0.001 \\
\hline $\mathrm{AGE} \geq \mathbf{6 5}^{a}$ & -0.099 & 0.025 & -3.890 & 0.000 & -0.110 & 0.025 & -4.370 & 0.000 & 2.04 & -0.185 & 0.024 & -7.610 & 0.000 \\
\hline $\begin{array}{l}\text { ARTIFICIAL RES- } \\
\text { PIRATION }^{a}\end{array}$ & -0.345 & 0.048 & -7.180 & 0.000 & -0.355 & 0.048 & $-7 \cdot 330$ & 0.000 & 1.19 & -0.377 & 0.046 & -8.230 & 0.000 \\
\hline $\begin{array}{l}\text { SPECIAL FACILITY } \\
\text { HIV }{ }^{a}\end{array}$ & -12.52 & 2.386 & -5.250 & 0.000 & -22.39 & 4.256 & -5.260 & 0.000 & 1.74 & -22.74 & 4.067 & $-5 \cdot 590$ & 0.000 \\
\hline $\begin{array}{l}\text { SPECIAL FACILITY } \\
\text { CYSTIC FYBROSIS }{ }^{a}\end{array}$ & -3.519 & 2.802 & -1.260 & 0.209 & -3.343 & 2.885 & -1.160 & 0.247 & 1.04 & -4.633 & 2.790 & -1.660 & 0.097 \\
\hline $\begin{array}{l}\text { SPECIAL FACILITY } \\
\text { BURN INJURY }{ }^{a}\end{array}$ & -10.15 & 2.287 & -4.440 & 0.000 & -11.15 & 2.280 & -4.890 & 0.000 & 1.05 & -12.11 & 2.195 & $-5 \cdot 520$ & 0.000 \\
\hline $\begin{array}{l}\text { SPECIAL FACILITY } \\
\text { BRAIN INJURY }\end{array}$ & -0.128 & 0.074 & -1.730 & 0.084 & -0.122 & 0.073 & -1.660 & 0.098 & 1.11 & -0.143 & 0.071 & -2.020 & 0.043 \\
\hline $\begin{array}{l}\text { TRANSPLANTA- } \\
\text { TION }{ }^{a}\end{array}$ & -2.973 & 1.085 & -2.740 & 0.006 & -4.001 & 1.151 & -3.480 & 0.001 & 1.06 & -4.719 & 1.107 & -4.260 & 0.000 \\
\hline $\begin{array}{l}\text { ACUTE MYOCAR- } \\
\text { DIAL INFARCTIONa }\end{array}$ & -2.410 & 0.689 & -3.500 & 0.000 & -2.235 & 0.686 & -3.260 & 0.001 & 1.48 & -3.125 & 0.663 & -4.710 & 0.000 \\
\hline $\begin{array}{l}\text { CONGESTIVE } \\
\text { HEART FAILURE }{ }^{a}\end{array}$ & 0.393 & 0.212 & 1.860 & 0.064 & 0.463 & 0.210 & 2.200 & 0.028 & 1.50 & 0.368 & 0.202 & 1.820 & 0.068 \\
\hline
\end{tabular}


BuR - Business Research

Official Open Access Journal of VHB

Verband der Hochschullehrer für Betriebswirtschaft e.V.

Volume 2 | Issue 2 | December 2009 | 115-145

Appendix 3 continued: Regression results for each model - full model specification

\begin{tabular}{|c|c|c|c|c|c|c|c|c|c|c|c|c|c|}
\hline \multirow{2}{*}{$\begin{array}{l}\text { Independent vari- } \\
\text { ables }\end{array}$} & \multicolumn{4}{|l|}{ DEA I } & \multicolumn{5}{|c|}{ DEA II } & \multicolumn{4}{|c|}{ DEA III } \\
\hline & $\begin{array}{l}\text { Coeff- } \\
\text { cients }\end{array}$ & $\begin{array}{l}\text { Standard } \\
\text { error }\end{array}$ & z-value & p-value & $\begin{array}{l}\text { Coeffi- } \\
\text { cients }\end{array}$ & $\begin{array}{l}\text { Standard } \\
\text { error }\end{array}$ & z-value & p-value & $\begin{array}{l}\text { Variance } \\
\text { inflation } \\
\text { factor }\end{array}$ & $\begin{array}{l}\text { Coeffi- } \\
\text { cients }\end{array}$ & $\begin{array}{l}\text { Standard } \\
\text { error }\end{array}$ & z-value & p-value \\
\hline \multicolumn{14}{|l|}{ Case-mix variables } \\
\hline $\begin{array}{l}\text { PERIPHERAL VAS- } \\
\text { CULAR DISEASE }^{a}\end{array}$ & -2.218 & 0.791 & 2.800 & 0.005 & -1.766 & 0.790 & -2.240 & 0.025 & 1.02 & -1.996 & 0.765 & -2.610 & 0.009 \\
\hline $\begin{array}{l}\text { CEREBRAL VAS- } \\
\text { CULAR ACCIDENT }{ }^{a}\end{array}$ & 0.407 & 0.212 & 1.920 & 0.055 & 0.398 & 0.210 & 1.900 & 0.058 & 1.40 & 0.078 & 0.203 & -0.390 & 0.699 \\
\hline DEMENTIA $^{a}$ & -0.792 & 0.427 & -1.860 & 0.063 & -0.760 & 0.422 & -1.800 & 0.072 & 1.20 & 0.556 & 0.417 & 1.330 & 0.183 \\
\hline $\begin{array}{l}\text { PULMONARY } \\
\text { DISEASE }^{a}\end{array}$ & 1.086 & 0.339 & 3.200 & 0.001 & 1.158 & 0.336 & 3.450 & 0.001 & 1.10 & 0.618 & 0.320 & 1.930 & 0.053 \\
\hline $\begin{array}{l}\text { CONNECTIVE TIS- } \\
\text { SUE DISORDER }^{a}\end{array}$ & -0.469 & 0.094 & -5.010 & 0.000 & -0.455 & 0.093 & -4.910 & 0.000 & 1.05 & 0.026 & 0.092 & 0.280 & 0.779 \\
\hline PEPTIC ULCER ${ }^{a}$ & 3.898 & 1.384 & 2.820 & 0.005 & 3.063 & 1.371 & 2.230 & 0.025 & 1.46 & -1.795 & 1.323 & -1.360 & 0.175 \\
\hline LIVER DISEASE ${ }^{a}$ & 0.795 & 0.494 & 1.610 & 0.108 & 1.028 & 0.500 & 2.050 & 0.040 & 1.33 & 0.721 & 0.465 & 1.550 & 0.121 \\
\hline DIABETES $a$ & 0.777 & 0.249 & 3.120 & 0.002 & 0.748 & 0.244 & 3.060 & 0.002 & 1.06 & 0.325 & 0.231 & 1.410 & 0.160 \\
\hline $\begin{array}{l}\text { DIABETES COM- } \\
\text { PLICATIONS }^{a}\end{array}$ & -0.920 & 0.946 & -0.970 & 0.331 & -0.391 & 0.944 & -0.410 & 0.679 & 1.11 & -0.014 & 0.922 & -0.020 & 0.988 \\
\hline PARAPLEGIA ${ }^{a}$ & -8.831 & 1.393 & -6.340 & 0.000 & -8.758 & 1.376 & -6.360 & 0.000 & 1.08 & -7.220 & 1.207 & -5.980 & 0.000 \\
\hline RENAL DISEASE ${ }^{a}$ & -0.172 & 0.199 & -0.860 & 0.387 & -0.153 & 0.197 & -0.780 & 0.438 & 1.17 & 0.327 & 0.211 & 1.550 & 0.121 \\
\hline CANCER $^{a}$ & -0.715 & 0.419 & -1.710 & 0.088 & -0.299 & 0.427 & -0.700 & 0.484 & 1.19 & -1.032 & 0.413 & -2.500 & 0.013 \\
\hline $\begin{array}{l}\text { METASTATIC CAN- } \\
\text { CER }^{a}\end{array}$ & -0.373 & 0.352 & -1.060 & 0.290 & -0.490 & 0.350 & -1.400 & 0.161 & 1.18 & -1.072 & 0.339 & -3.160 & 0.002 \\
\hline $\begin{array}{l}\text { SEVERE LIVER } \\
\text { DISEASE }^{a}\end{array}$ & 6.619 & 5.888 & 1.120 & 0.261 & $7 \cdot 752$ & 5.923 & 1.310 & 0.191 & 1.40 & -0.591 & 5.731 & -0.100 & 0.918 \\
\hline
\end{tabular}


Appendix 3 continued: Regression results for each model - full model specification

\begin{tabular}{|c|c|c|c|c|c|c|c|c|c|c|c|c|c|}
\hline \multirow[t]{2}{*}{$\begin{array}{l}\text { Independent vari- } \\
\text { ables }\end{array}$} & \multicolumn{4}{|l|}{ DEA I } & \multicolumn{5}{|c|}{ DEA II } & \multicolumn{4}{|c|}{ DEA III } \\
\hline & $\begin{array}{l}\text { Coeffi- } \\
\text { cients }\end{array}$ & $\begin{array}{l}\text { Standard } \\
\text { error }\end{array}$ & z-value & p-value & $\begin{array}{l}\text { Coeffi- } \\
\text { cients }\end{array}$ & $\begin{array}{l}\text { Standard } \\
\text { error }\end{array}$ & z-value & p-value & $\begin{array}{l}\text { Variance } \\
\text { inflation } \\
\text { factor }\end{array}$ & $\begin{array}{l}\text { Coeffi- } \\
\text { cients }\end{array}$ & $\begin{array}{l}\text { Standard } \\
\text { error }\end{array}$ & z-value & p-value \\
\hline \multicolumn{14}{|l|}{ Case-mix variables } \\
\hline HIVa & -166.8 & 128.2 & -1.300 & 0.193 & -138.6 & 130.5 & -1.060 & 0.288 & 1.74 & -144.0 & 126.4 & -1.140 & 0.255 \\
\hline
\end{tabular}

\begin{tabular}{|c|c|c|c|c|c|c|c|c|c|c|c|c|c|}
\hline \multicolumn{14}{|l|}{ Years } \\
\hline YEAR 2003 & 0.017 & 0.006 & 2.720 & 0.006 & 0.017 & 0.006 & 2.750 & 0.006 & 1.61 & 0.014 & 0.006 & 2.300 & 0.021 \\
\hline YEAR 2004 & 0.022 & 0.006 & 3.480 & 0.000 & 0.027 & 0.006 & 4.280 & 0.000 & 1.68 & 0.026 & 0.006 & 4.230 & 0.000 \\
\hline YEAR 2005 & 0.024 & 0.006 & 3.750 & 0.000 & 0.030 & 0.006 & 4.710 & 0.000 & 1.83 & 0.036 & 0.006 & $5 \cdot 710$ & 0.000 \\
\hline YEAR 2006 & 0.052 & 0.007 & 8.010 & 0.000 & 0.054 & 0.007 & 8.280 & 0.000 & 2.04 & 0.040 & 0.006 & 6.290 & 0.000 \\
\hline INTERCEPT & 0.576 & 0.010 & 58.03 & 0.000 & 0.567 & 0.010 & 57.06 & 0.000 & & 0.662 & 0.010 & 68.53 & 0.000 \\
\hline PSEUDO-R² & 0.146 & & & & 0.161 & & & & & 0.157 & & & \\
\hline
\end{tabular}

a Share of all cases per hospital

${ }^{*} p \leq 0.05 ;{ }^{* *} p \leq 0.01 ;{ }^{* * * *} p \leq 0.001$ 
BuR - Business Research

Ficial Open Access Journal of VHB

.

Volume 2 | Issue 2 | December 2009 | 115-145

Appendix 4: Regression results - modification of the number of periods used ${ }^{\text {a }}$

\begin{tabular}{|c|c|c|c|c|c|c|c|c|c|c|c|c|c|c|c|c|}
\hline \multirow[t]{2}{*}{$\begin{array}{l}\text { Independent vari- } \\
\text { ables }\end{array}$} & \multicolumn{4}{|c|}{ YEARS 2002-2006 } & \multicolumn{4}{|c|}{ YEARS 2003-2006 } & \multicolumn{4}{|c|}{ YEARS 2004-2006 } & \multicolumn{4}{|c|}{ YEARS 2005-2006 } \\
\hline & $\begin{array}{l}\text { Coeffi- } \\
\text { cients }\end{array}$ & $\begin{array}{l}\text { Standard } \\
\text { error }\end{array}$ & z-value & p-value & $\begin{array}{l}\text { Coeffi- } \\
\text { cients }\end{array}$ & $\begin{array}{l}\text { Standard } \\
\text { error }\end{array}$ & z-value & p-value & $\begin{array}{l}\text { Coeffi- } \\
\text { cients }\end{array}$ & $\begin{array}{l}\text { Standard } \\
\text { error }\end{array}$ & z-value & p-value & $\begin{array}{l}\text { Coeffi- } \\
\text { cients }\end{array}$ & $\begin{array}{l}\text { Standard } \\
\text { error }\end{array}$ & z-value & $p$-value \\
\hline \multicolumn{17}{|l|}{ Ownership } \\
\hline PUBLIC & 0.023 & 0.007 & 3.380 & 0.001 & 0.021 & 0.007 & 2.880 & 0.004 & 0.019 & 0.009 & 2.150 & 0.031 & 0.020 & 0.011 & 1.870 & 0.062 \\
\hline PRIVATE-NP & 0.010 & 0.007 & 1.450 & 0.147 & 0.008 & 0.007 & 1.080 & 0.279 & 0.007 & 0.009 & 0.760 & 0.446 & 0.008 & 0.011 & 0.710 & 0.477 \\
\hline PRIVATE-FP & \multicolumn{16}{|c|}{ served as reference category } \\
\hline
\end{tabular}

\begin{tabular}{|c|c|c|c|c|c|c|c|c|c|c|c|c|c|c|c|c|}
\hline $\begin{array}{l}\text { Organizational and } \\
\text { environmental vari- } \\
\text { ables }\end{array}$ & & & & & & & & & & & & & & & & \\
\hline HHI & 0.085 & 0.010 & 8.860 & 0.000 & 0.084 & 0.011 & 7.910 & 0.000 & 0.085 & 0.012 & 6.990 & 0.000 & 0.091 & 0.015 & 6.130 & 0.000 \\
\hline BEDS (in thousands) & 0.085 & 0.011 & 8.040 & 0.000 & 0.076 & 0.012 & 6.530 & 0.000 & 0.087 & 0.013 & 6.510 & 0.000 & 0.088 & 0.016 & $5 \cdot 340$ & 0.000 \\
\hline EAST & 0.012 & 0.006 & 2.060 & 0.040 & 0.012 & 0.006 & 1.940 & 0.052 & 0.011 & 0.007 & 1.470 & 0.141 & 0.005 & 0.009 & 0.570 & 0.570 \\
\hline AMBULATORY & -0.019 & 0.005 & -3.750 & 0.000 & -0.020 & 0.006 & -3.480 & 0.001 & -0.018 & 0.007 & -2.660 & 0.008 & -0.016 & 0.008 & -1.960 & 0.050 \\
\hline HIRED BEDS & 0.054 & 0.016 & 3.250 & 0.001 & 0.038 & 0.018 & 2.090 & 0.037 & 0.026 & 0.021 & 1.210 & 0.226 & 0.025 & 0.026 & 0.970 & 0.330 \\
\hline TEACH & 0.003 & 0.005 & 0.750 & 0.454 & 0.006 & 0.005 & 1.210 & 0.227 & 0.007 & 0.005 & 1.340 & 0.179 & 0.008 & 0.005 & 1.440 & 0.150 \\
\hline CONVERSION & 0.002 & 0.009 & 0.180 & 0.859 & 0.002 & 0.011 & 0.200 & 0.839 & 0.001 & 0.013 & 0.070 & 0.948 & -0.003 & 0.016 & -0.160 & 0.875 \\
\hline
\end{tabular}


Appendix 4 continued: Regression results - modification of the number of periods used ${ }^{a}$

\begin{tabular}{|c|c|c|c|c|c|c|c|c|c|c|c|c|c|c|c|c|}
\hline \multirow{2}{*}{$\begin{array}{l}\text { Independent vari- } \\
\text { ables }\end{array}$} & \multicolumn{4}{|c|}{ YEARS 2002-2006 } & \multicolumn{4}{|c|}{ YEARS 2003-2006 } & \multicolumn{4}{|c|}{ YEARS 2004-2006 } & \multicolumn{4}{|c|}{ YEARS 2005-2006 } \\
\hline & $\begin{array}{l}\text { Coeffi- } \\
\text { cients }\end{array}$ & $\begin{array}{l}\text { Standard } \\
\text { error }\end{array}$ & z-value & p-value & $\begin{array}{l}\text { Coeffi- } \\
\text { cients }\end{array}$ & $\begin{array}{l}\text { Standard } \\
\text { error }\end{array}$ & z-value & p-value & $\begin{array}{l}\text { Coeffi- } \\
\text { cients }\end{array}$ & $\begin{array}{l}\text { Standard } \\
\text { error }\end{array}$ & z-value & p-value & $\begin{array}{l}\text { Coeffi- } \\
\text { cients }\end{array}$ & $\begin{array}{l}\text { Standard } \\
\text { error }\end{array}$ & z-value & p-value \\
\hline \multicolumn{17}{|l|}{ Case-mix variables } \\
\hline $\begin{array}{l}\text { AVAILAB. PET } \\
\text { (yes/no) }\end{array}$ & 0.008 & 0.014 & 0.530 & 0.599 & 0.013 & 0.016 & 3.220 & 0.403 & 0.002 & 0.018 & 0.120 & 0.907 & 0.002 & 0.021 & 0.100 & 0.924 \\
\hline $\begin{array}{l}\text { AVAILAB. CARD. } \\
\text { CATH. LAB. } \\
\text { (yes/no) }\end{array}$ & 0.024 & 0.006 & 3.820 & 0.000 & 0.022 & 0.007 & 0.840 & 0.001 & 0.016 & 0.008 & 1.950 & 0.051 & 0.005 & 0.010 & 0.540 & 0.592 \\
\hline $\mathrm{AGE} \geq \mathbf{6 5}^{b}$ & -0.110 & 0.025 & $-4 \cdot 370$ & 0.000 & -0.109 & 0.028 & -3.880 & 0.000 & -0.151 & 0.033 & -4.580 & 0.000 & -0.167 & 0.039 & -4.230 & 0.000 \\
\hline $\begin{array}{l}\text { ARTIFICIAL RES- } \\
\text { PIRATION }^{b}\end{array}$ & -0.355 & 0.048 & $-7 \cdot 330$ & 0.000 & -0.331 & 0.049 & -6.710 & 0.000 & -0.338 & 0.059 & $-5 \cdot 700$ & 0.000 & -0.365 & 0.087 & -4.200 & 0.000 \\
\hline $\begin{array}{l}\text { SPECIAL FACILITY } \\
\text { HIV }^{b}\end{array}$ & -22.39 & 4.256 & -5.260 & 0.000 & -9.821 & 2.965 & -3.310 & 0.001 & -28.92 & 6.291 & -4.600 & 0.000 & -33.98 & 8.217 & -4.140 & 0.000 \\
\hline $\begin{array}{l}\text { SPECIAL FACILITY } \\
\text { CYSTIC FYBROSIS }^{b}\end{array}$ & $-3 \cdot 343$ & 2.885 & -1.160 & 0.247 & -2.067 & 3.203 & -0.650 & 0.519 & -2.015 & 3.923 & -0.510 & 0.608 & 0.062 & 5.208 & 0.010 & 0.990 \\
\hline $\begin{array}{l}\text { SPECIAL FACILITY } \\
\text { BURN INJURY }^{b}\end{array}$ & -11.15 & 2.280 & -4.890 & 0.000 & -13.02 & 2.624 & -4.960 & 0.000 & -13.49 & 3.104 & -4.350 & 0.000 & -10.84 & 4.183 & -2.590 & 0.010 \\
\hline $\begin{array}{l}\text { SPECIAL FACILITY } \\
\text { BRAIN INJURY }^{b}\end{array}$ & -0.122 & 0.073 & -1.660 & 0.098 & -0.119 & 0.074 & -1.600 & 0.109 & -0.102 & 0.075 & -1.360 & 0.173 & -0.093 & 0.077 & -1.210 & 0.228 \\
\hline $\begin{array}{l}\text { TRANSPLANTA- } \\
\text { TION }^{b}\end{array}$ & -4.001 & 1.151 & -3.480 & 0.001 & -3.813 & 1.144 & -3.330 & 0.001 & -3.709 & 1.178 & -3.150 & 0.002 & -2.655 & 1.725 & -1.540 & 0.124 \\
\hline $\begin{array}{l}\text { ACUTE MYOCAR- } \\
\text { DIAL INFARCTION } b\end{array}$ & -2.235 & 0.686 & -3.260 & 0.001 & -2.384 & 0.748 & -3.190 & 0.001 & -2.188 & 0.906 & -2.410 & 0.016 & -1.684 & 1.303 & -1.290 & 0.196 \\
\hline $\begin{array}{l}\text { CONGESTIVE } \\
\text { HEART FAILURE }{ }^{b}\end{array}$ & 0.463 & 0.210 & 2.200 & 0.028 & 0.568 & 0.283 & 2.010 & 0.045 & 1.622 & 0.458 & 3.540 & 0.000 & 2.112 & 0.599 & 3.530 & 0.000 \\
\hline
\end{tabular}


Appendix 4 continued: Regression results - modification of the number of periods used ${ }^{\text {a }}$

\begin{tabular}{|c|c|c|c|c|c|c|c|c|c|c|c|c|c|c|c|c|}
\hline \multirow[t]{2}{*}{$\begin{array}{l}\text { Independent vari- } \\
\text { ables }\end{array}$} & \multicolumn{4}{|c|}{ YEARS 2002-2006 } & \multicolumn{4}{|c|}{ YEARS 2003-2006 } & \multicolumn{4}{|c|}{ YEARS 2004-2006 } & \multicolumn{4}{|c|}{ YEARS 2005-2006 } \\
\hline & $\begin{array}{l}\text { Coeffi- } \\
\text { cients }\end{array}$ & $\begin{array}{l}\text { Standard } \\
\text { error }\end{array}$ & z-value & p-value & $\begin{array}{l}\text { Coeffi- } \\
\text { cients }\end{array}$ & $\begin{array}{l}\text { Standard } \\
\text { error }\end{array}$ & z-value & p-value & $\begin{array}{l}\text { Coeffi- } \\
\text { cients }\end{array}$ & $\begin{array}{l}\text { Standard } \\
\text { error }\end{array}$ & z-value & p-value & $\begin{array}{l}\text { Coeffi- } \\
\text { cients }\end{array}$ & $\begin{array}{l}\text { Standard } \\
\text { error }\end{array}$ & z-value & p-value \\
\hline \multicolumn{17}{|l|}{ Case-mix variables } \\
\hline $\begin{array}{l}\text { PERIPHERAL VAS- } \\
\text { CULAR DISEASE }^{b}\end{array}$ & -1.766 & 0.790 & -2.240 & 0.025 & -2.307 & 0.974 & -2.370 & 0.018 & -2.328 & 1.323 & -1.760 & 0.079 & -5.261 & 2.437 & -2.160 & 0.031 \\
\hline $\begin{array}{l}\text { CEREBRAL VAS- } \\
\text { CULAR ACCIDENT }{ }^{b}\end{array}$ & 0.398 & 0.210 & 1.900 & 0.058 & 0.319 & 0.216 & 1.480 & 0.139 & 0.204 & 0.247 & 0.820 & 0.410 & 0.138 & 0.290 & 0.480 & 0.633 \\
\hline DEMENTIA $^{b}$ & -0.760 & 0.422 & -1.800 & 0.072 & -0.887 & 0.457 & -1.940 & 0.052 & -0.723 & 0.500 & -1.450 & 0.148 & -0.823 & 0.573 & -1.440 & 0.151 \\
\hline $\begin{array}{l}\text { PULMONARY } \\
\text { DISEASE }^{b}\end{array}$ & 1.158 & 0.336 & 3.450 & 0.001 & 1.140 & 0.385 & 2.960 & 0.003 & 1.659 & 0.495 & $3 \cdot 350$ & 0.001 & 1.199 & 0.554 & 2.160 & 0.031 \\
\hline $\begin{array}{l}\text { CONNECTIVE TIS- } \\
\text { SUE DISORDER }^{b}\end{array}$ & -0.455 & 0.093 & -4.910 & 0.000 & -0.416 & 0.101 & -4.110 & 0.000 & -0.400 & 0.113 & -3.520 & 0.000 & -0.402 & 0.141 & -2.860 & 0.004 \\
\hline PEPTIC ULCER ${ }^{b}$ & 3.063 & 1.371 & 2.230 & 0.025 & 2.783 & 1.496 & 1.860 & 0.063 & 3.217 & 1.722 & 1.870 & 0.062 & 4.739 & 2.141 & 2.210 & 0.027 \\
\hline LIVER DISEASE $^{b}$ & 1.028 & 0.500 & 2.050 & 0.040 & 1.172 & 0.588 & 2.000 & 0.046 & 0.710 & 0.708 & 1.000 & 0.316 & 0.430 & 0.951 & 0.450 & 0.651 \\
\hline DIABETES $^{b}$ & 0.748 & 0.244 & 3.060 & 0.002 & 0.656 & 0.265 & 2.480 & 0.013 & 0.580 & 0.309 & 1.880 & 0.060 & 0.750 & 0.490 & 1.530 & 0.126 \\
\hline $\begin{array}{l}\text { DIABETES COM- } \\
\text { PLICATIONS }^{b}\end{array}$ & -0.391 & 0.944 & -0.410 & 0.679 & -0.131 & 1.286 & -0.100 & 0.919 & 0.780 & 1.497 & 0.520 & 0.602 & 1.215 & 1.767 & 0.690 & 0.492 \\
\hline PARAPLEGIA $^{b}$ & -8.758 & 1.376 & -6.360 & 0.000 & -7.137 & 1.253 & -5.700 & 0.000 & -6.023 & 1.312 & -4.590 & 0.000 & -4.660 & 1.413 & -3.300 & 0.001 \\
\hline RENAL DISEASE $^{b}$ & -0.153 & 0.197 & -0.780 & 0.438 & -0.171 & 0.284 & -0.600 & 0.548 & -1.305 & 1.445 & -0.900 & 0.366 & -4.263 & 2.582 & -1.650 & 0.099 \\
\hline CANCER $^{b}$ & -0.299 & 0.427 & -0.700 & 0.484 & -0.738 & 0.387 & -1.910 & 0.057 & -0.492 & 0.464 & -1.060 & 0.289 & -0.528 & 0.652 & -0.810 & 0.418 \\
\hline $\begin{array}{l}\text { METASTATIC CAN- } \\
\text { CER }^{b}\end{array}$ & -0.490 & 0.350 & -1.400 & 0.161 & -0.370 & 0.389 & -0.950 & 0.342 & -0.264 & 0.467 & -0.570 & 0.571 & -0.690 & 0.741 & -0.930 & 0.352 \\
\hline $\begin{array}{l}\text { SEVERE LIVER } \\
\text { DISEASE }^{b}\end{array}$ & $7 \cdot 75^{2}$ & 5.923 & 1.310 & 0.191 & 7.262 & 6.534 & 1.110 & 0.266 & 5.102 & 7.798 & 0.650 & 0.513 & 6.268 & 12.99 & 0.480 & 0.629 \\
\hline
\end{tabular}


Appendix 4 continued: Regression results - modification of the number of periods used ${ }^{\text {a }}$

\begin{tabular}{|c|c|c|c|c|c|c|c|c|c|c|c|c|c|c|c|c|}
\hline \multirow[t]{2}{*}{$\begin{array}{l}\text { Independent vari- } \\
\text { ables }\end{array}$} & \multicolumn{4}{|c|}{ YEARS 2002-2006 } & \multicolumn{4}{|c|}{ YEARS 2003-2006 } & \multicolumn{4}{|c|}{ YEARS 2004-2006 } & \multicolumn{4}{|c|}{ YEARS 2005-2006 } \\
\hline & $\begin{array}{l}\text { Coeffi- } \\
\text { cients }\end{array}$ & $\begin{array}{l}\text { Standard } \\
\text { error }\end{array}$ & z-value & p-value & $\begin{array}{l}\text { Coeffi- } \\
\text { cients }\end{array}$ & $\begin{array}{l}\text { Standard } \\
\text { error }\end{array}$ & z-value & $p$-value & $\begin{array}{l}\text { Coeffi- } \\
\text { cients }\end{array}$ & $\begin{array}{l}\text { Standard } \\
\text { error }\end{array}$ & z-value & p-value & $\begin{array}{l}\text { Coeffi- } \\
\text { cients }\end{array}$ & $\begin{array}{l}\text { Standard } \\
\text { error }\end{array}$ & z-value & p-value \\
\hline \multicolumn{17}{|l|}{ Case-mix variables } \\
\hline HIV b & -138.6 & 130.5 & -1.060 & 0.288 & -15.76 & 71.84 & -0.220 & 0.826 & -65.83 & 79.80 & -0.830 & 0.409 & -19.65 & 108.9 & -0.180 & 0.857 \\
\hline
\end{tabular}

\section{Years}

\begin{tabular}{|c|c|c|c|c|c|c|c|c|c|c|c|c|c|c|c|c|}
\hline YEAR 2003 & 0.017 & 0.006 & 2.750 & 0.006 & & & & & & & & & & & & \\
\hline YEAR 2004 & 0.027 & 0.006 & 4.280 & 0.000 & 0.010 & 0.006 & 1.630 & 0.103 & & & & & & & & \\
\hline YEAR 2005 & 0.030 & 0.006 & 4.710 & 0.000 & 0.012 & 0.006 & 1.960 & 0.050 & 0.003 & 0.006 & 0.430 & 0.666 & & & & \\
\hline YEAR 2006 & 0.054 & 0.007 & 8.280 & 0.000 & 0.036 & 0.006 & 5.580 & 0.000 & 0.027 & 0.006 & 4.110 & 0.000 & 0.024 & 0.006 & 3.950 & 0.000 \\
\hline INTERCEPT & 0.567 & 0.010 & 57.06 & 0.000 & 0.591 & 0.011 & 54.25 & 0.000 & 0.603 & 0.013 & 47.94 & 0.000 & 0.606 & 0.015 & 40.33 & 0.000 \\
\hline PSEUDO-R² & 0.161 & & & & 0.136 & & & & 0.142 & & & & 0.142 & & & \\
\hline
\end{tabular}

aDEA II - Efficiency model including hospitals with beds $\geq 50$, without university hospitals.

${ }^{b}$ Share of all cases per hospital. 
Appendix 5: Regression results - modification in terms of hospital sizea

\begin{tabular}{|c|c|c|c|c|c|c|c|c|c|c|c|c|c|c|c|c|}
\hline \multirow[t]{2}{*}{$\begin{array}{l}\text { Independent vari- } \\
\text { ables }\end{array}$} & \multicolumn{4}{|c|}{ BEDS $>30$} & \multicolumn{4}{|c|}{ BEDS $>50$} & \multicolumn{4}{|c|}{ BEDS $>70$} & \multicolumn{4}{|c|}{ BEDS $>100$} \\
\hline & $\begin{array}{l}\text { Coeffi- } \\
\text { cients }\end{array}$ & $\begin{array}{l}\text { Standard } \\
\text { error }\end{array}$ & z-value & p-value & $\begin{array}{l}\text { Coeffi- } \\
\text { cients }\end{array}$ & $\begin{array}{l}\text { Standard } \\
\text { error }\end{array}$ & z-value & p-value & $\begin{array}{l}\text { Coeffi- } \\
\text { cients }\end{array}$ & $\begin{array}{l}\text { Standard } \\
\text { error }\end{array}$ & z-value & p-value & $\begin{array}{l}\text { Coeffi- } \\
\text { cients }\end{array}$ & $\begin{array}{l}\text { Standard } \\
\text { error }\end{array}$ & z-value & $p$-value \\
\hline \multicolumn{17}{|l|}{ Ownership } \\
\hline PUBLIC & 0.028 & 0.006 & 4.340 & 0.000 & 0.023 & 0.007 & 3.380 & 0.001 & 0.022 & 0.006 & 3.510 & 0.000 & 0.027 & 0.007 & 3.780 & 0.000 \\
\hline PRIVATE-NP & 0.012 & 0.006 & 1.840 & 0.065 & 0.010 & 0.007 & 1.450 & 0.147 & 0.005 & 0.006 & 0.750 & 0.456 & 0.016 & 0.007 & 2.190 & 0.029 \\
\hline PRIVATE-FP & served & erence ca & egory & & & & & & & & & & & & & \\
\hline
\end{tabular}

\begin{tabular}{|c|c|c|c|c|c|c|c|c|c|c|c|c|c|c|c|c|}
\hline $\begin{array}{l}\text { Organizational and } \\
\text { environmental vari- } \\
\text { ables }\end{array}$ & & & & & & & & & & & & & & & & \\
\hline HHI & 0.076 & 0.009 & 8.180 & 0.000 & 0.085 & 0.010 & 8.860 & 0.000 & 0.070 & 0.009 & 7.490 & 0.000 & 0.046 & 0.010 & 4.790 & 0.000 \\
\hline BEDS (in thousands) & 0.109 & 0.011 & 10.16 & 0.000 & 0.085 & 0.011 & 8.040 & 0.000 & 0.024 & 0.021 & 1.160 & 0.247 & 0.058 & 0.021 & 2.700 & 0.007 \\
\hline EAST & 0.022 & 0.006 & 3.910 & 0.000 & 0.012 & 0.006 & 2.060 & 0.040 & 0.013 & 0.006 & 2.270 & 0.023 & 0.026 & 0.006 & $4 \cdot 300$ & 0.000 \\
\hline AMBULATORY & -0.010 & 0.005 & -1.980 & 0.047 & -0.019 & 0.005 & -3.750 & 0.000 & -0.019 & 0.005 & -3.970 & 0.000 & -0.016 & 0.005 & -3.060 & 0.002 \\
\hline HIRED BEDS & 0.072 & 0.017 & $4 \cdot 340$ & 0.000 & 0.054 & 0.016 & 3.250 & 0.001 & 0.060 & 0.016 & 3.730 & 0.000 & 0.171 & 0.022 & 7.650 & 0.000 \\
\hline TEACH & 0.010 & 0.005 & 2.160 & 0.031 & 0.003 & 0.005 & 0.750 & 0.454 & 0.010 & 0.005 & 2.150 & 0.031 & 0.021 & 0.005 & 4.700 & 0.000 \\
\hline CONVERSION & 0.001 & 0.009 & 0.070 & 0.942 & 0.002 & 0.009 & 0.180 & 0.859 & 0.001 & 0.009 & 0.130 & 0.897 & 0.014 & 0.009 & 1.490 & 0.136 \\
\hline
\end{tabular}


Appendix 5 continued: Regression results - modification in terms of hospital sizea

\begin{tabular}{|c|c|c|c|c|c|c|c|c|c|c|c|c|c|c|c|c|}
\hline \multirow{2}{*}{$\begin{array}{l}\text { Independent vari- } \\
\text { ables }\end{array}$} & \multicolumn{4}{|c|}{ BEDS $>\mathbf{3 0}$} & \multicolumn{4}{|c|}{ BEDS $>50$} & \multicolumn{4}{|c|}{ BEDS $>70$} & \multicolumn{4}{|c|}{ BEDS $>100$} \\
\hline & $\begin{array}{l}\text { Coeffi- } \\
\text { cients }\end{array}$ & $\begin{array}{l}\text { Standard } \\
\text { error }\end{array}$ & z-value & p-value & $\begin{array}{l}\text { Coeffi- } \\
\text { cients }\end{array}$ & $\begin{array}{l}\text { Standard } \\
\text { error }\end{array}$ & z-value & p-value & $\begin{array}{l}\text { Coeffi- } \\
\text { cients }\end{array}$ & $\begin{array}{l}\text { Standard } \\
\text { error }\end{array}$ & z-value & p-value & $\begin{array}{l}\text { Coeffi- } \\
\text { cients }\end{array}$ & $\begin{array}{l}\text { Standard } \\
\text { error }\end{array}$ & z-value & p-value \\
\hline \multicolumn{17}{|l|}{ Case-mix variables } \\
\hline $\begin{array}{l}\text { AVAILAB. PET } \\
\text { (yes/no) }\end{array}$ & 0.009 & 0.014 & 0.630 & 0.527 & 0.008 & 0.014 & 0.530 & 0.599 & 0.026 & 0.014 & 1.810 & 0.070 & 0.020 & 0.014 & 1.470 & 0.142 \\
\hline $\begin{array}{l}\text { AVAILAB. CARD. } \\
\text { CATH. LAB. } \\
\text { (yes/no) }\end{array}$ & 0.026 & 0.006 & 4.270 & 0.000 & 0.024 & 0.006 & 3.820 & 0.000 & 0.013 & 0.006 & 2.210 & 0.027 & 0.012 & 0.006 & 1.980 & 0.048 \\
\hline $\mathrm{AGE} \geq \mathbf{6 5}^{b}$ & -0.196 & 0.026 & -7.640 & 0.000 & -0.110 & 0.025 & -4.370 & 0.000 & -0.124 & 0.020 & -6.040 & 0.000 & -0.387 & 0.033 & -11.70 & 0.000 \\
\hline $\begin{array}{l}\text { ARTIFICIAL RES- } \\
\text { PIRATION }^{b}\end{array}$ & -0.264 & 0.043 & -6.070 & 0.000 & -0.355 & 0.048 & $-7 \cdot 330$ & 0.000 & -0.463 & 0.049 & -9.380 & 0.000 & -0.201 & 0.082 & -2.460 & 0.014 \\
\hline $\begin{array}{l}\text { SPECIAL FACILITY } \\
\text { HIV } b\end{array}$ & -4.945 & 1.890 & -2.620 & 0.009 & -22.39 & 4.256 & -5.260 & 0.000 & -23.91 & 4.180 & -5.720 & 0.000 & -26.11 & 3.942 & -6.620 & 0.000 \\
\hline $\begin{array}{l}\text { SPECIAL FACILITY } \\
\text { CYSTIC FYBROSIS }^{b}\end{array}$ & -2.711 & 2.806 & -0.970 & 0.334 & -3.343 & 2.885 & -1.160 & 0.247 & -4.083 & 2.818 & -1.450 & 0.147 & -4.324 & 2.645 & -1.630 & 0.102 \\
\hline $\begin{array}{l}\text { SPECIAL FACILITY } \\
\text { BURN INJURY }\end{array}$ & -11.05 & 2.274 & -4.860 & 0.000 & -11.15 & 2.280 & -4.890 & 0.000 & -8.842 & 2.246 & -3.940 & 0.000 & -10.76 & 2.129 & -5.050 & 0.000 \\
\hline $\begin{array}{l}\text { SPECIAL FACILITY } \\
\text { BRAIN INJURY }^{b}\end{array}$ & -0.191 & 0.073 & -2.610 & 0.009 & -0.122 & 0.073 & -1.660 & 0.098 & -0.104 & 0.068 & -1.530 & 0.127 & -0.869 & 0.286 & -3.040 & 0.002 \\
\hline $\begin{array}{l}\text { TRANSPLANTA- } \\
\text { TION }^{b}\end{array}$ & -4.183 & 1.144 & -3.660 & 0.000 & -4.001 & 1.151 & -3.480 & 0.001 & -4.297 & 1.081 & -3.970 & 0.000 & -4.570 & 1.013 & -4.510 & 0.000 \\
\hline $\begin{array}{l}\text { ACUTE MYOCAR- } \\
\text { DIAL INFARCTION }^{b}\end{array}$ & -2.091 & 0.660 & -3.170 & 0.002 & -2.235 & 0.686 & -3.260 & 0.001 & 0.000 & 0.000 & -0.560 & 0.000 & 0.000 & 0.000 & -1.360 & 0.173 \\
\hline $\begin{array}{l}\text { CONGESTIVE } \\
\text { HEART FAILURE }{ }^{b}\end{array}$ & 0.246 & 0.208 & 1.180 & 0.237 & 0.463 & 0.210 & 2.200 & 0.028 & 0.000 & 0.000 & 2.660 & 0.008 & 0.000 & 0.000 & 5.590 & 0.000 \\
\hline
\end{tabular}


Appendix 5 continued: Regression results - modification in terms of hospital size ${ }^{a}$

\begin{tabular}{|c|c|c|c|c|c|c|c|c|c|c|c|c|c|c|c|c|}
\hline \multirow[t]{2}{*}{$\begin{array}{l}\text { Independent vari- } \\
\text { ables }\end{array}$} & \multicolumn{4}{|c|}{ BEDS $>\mathbf{3 0}$} & \multicolumn{4}{|c|}{ BEDS $>50$} & \multicolumn{4}{|c|}{ BEDS $>70$} & \multicolumn{4}{|c|}{ BEDS $>100$} \\
\hline & $\begin{array}{l}\text { Coeffi- } \\
\text { cients }\end{array}$ & $\begin{array}{l}\text { Standard } \\
\text { error }\end{array}$ & z-value & p-value & $\begin{array}{l}\text { Coeffi- } \\
\text { cients }\end{array}$ & $\begin{array}{l}\text { Standard } \\
\text { error }\end{array}$ & z-value & p-value & $\begin{array}{l}\text { Coeffi- } \\
\text { cients }\end{array}$ & $\begin{array}{l}\text { Standard } \\
\text { error }\end{array}$ & z-value & p-value & $\begin{array}{l}\text { Coeffi- } \\
\text { cients }\end{array}$ & $\begin{array}{l}\text { Standard } \\
\text { error }\end{array}$ & z-value & p-value \\
\hline Case-mix variables & -1.791 & 0.782 & -2.290 & 0.022 & -1.766 & 0.790 & -2.240 & 0.025 & 0.000 & 0.000 & -0.460 & 0.649 & 0.000 & 0.000 & 0.120 & 0.906 \\
\hline $\begin{array}{l}\text { PERIPHERAL VAS- } \\
\text { CULAR DISEASE }^{b}\end{array}$ & 0.236 & 0.202 & 1.170 & 0.243 & 0.398 & 0.210 & 1.900 & 0.058 & 0.000 & 0.000 & 1.380 & 0.168 & 0.000 & 0.000 & 2.570 & 0.010 \\
\hline $\begin{array}{l}\text { CEREBRAL VAS- } \\
\text { CULAR ACCIDENT }^{b}\end{array}$ & -1.509 & 0.420 & -3.590 & 0.000 & -0.760 & 0.422 & -1.800 & 0.072 & 0.000 & 0.000 & -3.870 & 0.000 & -0.001 & 0.000 & -6.210 & 0.000 \\
\hline DEMENTIA $^{b}$ & 0.457 & 0.326 & 1.400 & 0.161 & 1.158 & 0.336 & 3.450 & 0.001 & 0.000 & 0.000 & 4.120 & 0.000 & 0.000 & 0.000 & 3.940 & 0.000 \\
\hline $\begin{array}{l}\text { PULMONARY } \\
\text { DISEASE }^{b}\end{array}$ & -0.695 & 0.100 & -6.970 & 0.000 & -0.455 & 0.093 & -4.910 & 0.000 & 0.000 & 0.000 & -5.630 & 0.000 & 0.000 & 0.000 & -4.940 & 0.000 \\
\hline $\begin{array}{l}\text { CONNECTIVE TIS- } \\
\text { SUE DISORDER }^{b}\end{array}$ & $7 \cdot 734$ & 1.345 & 5.750 & 0.000 & 3.063 & 1.371 & 2.230 & 0.025 & 0.000 & 0.000 & 2.420 & 0.015 & 0.001 & 0.000 & 5.160 & 0.000 \\
\hline PEPTIC ULCER $^{b}$ & 0.516 & 0.465 & 1.110 & 0.267 & 1.028 & 0.500 & 2.050 & 0.040 & 0.000 & 0.000 & 2.940 & 0.003 & 0.000 & 0.000 & 1.600 & 0.111 \\
\hline LIVER DISEASE $^{b}$ & -0.217 & 0.360 & -0.600 & 0.547 & 0.748 & 0.244 & 3.060 & 0.002 & 0.000 & 0.000 & 1.970 & 0.048 & 0.000 & 0.000 & 1.560 & 0.118 \\
\hline DIABETES $^{b}$ & -0.624 & 0.931 & -0.670 & 0.503 & -0.391 & 0.944 & -0.410 & 0.679 & 0.000 & 0.000 & 0.480 & 0.632 & 0.000 & 0.000 & 0.430 & 0.671 \\
\hline $\begin{array}{l}\text { DIABETES COM- } \\
\text { PLICATIONS }^{b}\end{array}$ & -12.21 & 1.452 & -8.410 & 0.000 & -8.758 & 1.376 & -6.360 & 0.000 & -0.002 & 0.000 & -9.180 & 0.000 & -0.003 & 0.000 & -10.15 & 0.000 \\
\hline PARAPLEGIA $^{b}$ & -0.133 & 0.196 & -0.680 & 0.498 & -0.153 & 0.197 & -0.780 & 0.438 & 0.000 & 0.000 & -2.020 & 0.043 & 0.000 & 0.000 & -2.050 & 0.041 \\
\hline RENAL DISEASE $^{b}$ & -0.693 & 0.324 & -2.140 & 0.033 & -0.299 & 0.427 & -0.700 & 0.484 & 0.000 & 0.000 & 1.120 & 0.265 & 0.000 & 0.000 & 0.060 & 0.955 \\
\hline CANCER $^{b}$ & -1.299 & 0.335 & -3.880 & 0.000 & -0.490 & 0.350 & -1.400 & 0.161 & 0.000 & 0.000 & -2.230 & 0.026 & 0.000 & 0.000 & -3.420 & 0.001 \\
\hline $\begin{array}{l}\text { METASTATIC CAN- } \\
\text { CER }^{b}\end{array}$ & 2.741 & 5.592 & 0.490 & 0.624 & $7 \cdot 752$ & 5.923 & 1.310 & 0.191 & 0.001 & 0.001 & 1.890 & 0.058 & 0.002 & 0.001 & 2.840 & 0.005 \\
\hline $\begin{array}{l}\text { SEVERE LIVER } \\
\text { DISEASE }^{b}\end{array}$ & -1.791 & 0.782 & -2.290 & 0.022 & -1.766 & 0.790 & -2.240 & 0.025 & 0.000 & 0.000 & -0.460 & 0.649 & 0.000 & 0.000 & 0.120 & 0.906 \\
\hline
\end{tabular}


Appendix 5 continued: Regression results - modification in terms of hospital size ${ }^{a}$

\begin{tabular}{|c|c|c|c|c|c|c|c|c|c|c|c|c|c|c|c|c|}
\hline \multirow[t]{2}{*}{$\begin{array}{l}\text { Independent vari- } \\
\text { ables }\end{array}$} & \multicolumn{4}{|c|}{ BEDS $>30$} & \multicolumn{4}{|c|}{ BEDS $>50$} & \multicolumn{4}{|c|}{ BEDS $>70$} & \multicolumn{4}{|c|}{ BEDS $>100$} \\
\hline & $\begin{array}{l}\text { Coeffi- } \\
\text { cients }\end{array}$ & $\begin{array}{l}\text { Standard } \\
\text { error }\end{array}$ & z-value & p-value & $\begin{array}{l}\text { Coeffi- } \\
\text { cients }\end{array}$ & $\begin{array}{l}\text { Standard } \\
\text { error }\end{array}$ & z-value & $p$-value & $\begin{array}{l}\text { Coeffi- } \\
\text { cients }\end{array}$ & $\begin{array}{l}\text { Standard } \\
\text { error }\end{array}$ & z-value & p-value & $\begin{array}{l}\text { Coeffi- } \\
\text { cients }\end{array}$ & $\begin{array}{l}\text { Standard } \\
\text { error }\end{array}$ & z-value & p-value \\
\hline \multicolumn{17}{|l|}{ Case-mix variables } \\
\hline HIV $b$ & -34.45 & 66.75 & -0.520 & 0.606 & -138.6 & 130.5 & -1.060 & 0.288 & -0.026 & 0.010 & -2.680 & 0.007 & -0.034 & 0.010 & -3.530 & 0.000 \\
\hline
\end{tabular}

\section{Years}

\begin{tabular}{|c|c|c|c|c|c|c|c|c|c|c|c|c|c|c|c|c|}
\hline YEAR 2003 & -0.035 & 0.006 & -5.920 & 0.000 & 0.017 & 0.006 & 2.750 & 0.006 & 0.015 & 0.006 & 2.540 & 0.011 & 0.013 & 0.006 & 2.160 & 0.030 \\
\hline YEAR 2004 & 0.027 & 0.006 & 4.450 & 0.000 & 0.027 & 0.006 & 4.280 & 0.000 & 0.026 & 0.006 & 4.190 & 0.000 & 0.032 & 0.006 & 5.040 & 0.000 \\
\hline YEAR 2005 & 0.016 & 0.006 & 2.610 & 0.009 & 0.030 & 0.006 & 4.710 & 0.000 & 0.030 & 0.006 & 4.790 & 0.000 & 0.040 & 0.007 & 6.110 & 0.000 \\
\hline YEAR 2006 & 0.066 & 0.006 & 10.39 & 0.000 & 0.054 & 0.007 & 8.280 & 0.000 & 0.054 & 0.006 & 8.520 & 0.000 & 0.069 & 0.007 & 10.33 & 0.000 \\
\hline INTERCEPT & 0.560 & 0.010 & 58.21 & 0.000 & 0.567 & 0.010 & 57.060 & 0.000 & 0.580 & 0.009 & 61.16 & 0.000 & 0.581 & 0.012 & 49.21 & 0.000 \\
\hline PSEUDO-R² & 0.188 & & & & 0.161 & & & & 0.158 & & & & 0.206 & & & \\
\hline
\end{tabular}

a DEA II - Efficiency model including hospitals with beds $\geq 50$, without university hospitals.

${ }^{b}$ Share of all cases per hospital. 


\section{References}

Arrow, Kenneth Joseph (1963): Uncertainty and the welfare economics of medical care, American Economic Review, 53 (5): 941-973.

Banker, Rajiv D., Abraham Charnes, William W. Cooper, John Swarts, and Dave Thomas (1989): An introduction to data envelopment analysis with some of its models and their uses, Research in Government and Nonprofit Accounting, 5: 125-163.

Banker, Rajiv D., Abraham Charnes, and William W. Cooper (1984): Some models for estimating technical and scale inefficiencies in data envelopment analysis, Management Science, 30 (9): 1078-1092.

Bishop, Matthew and David Thompson (1992): Regulatory reform and productivity growth in the UK's public utilities, Applied Economics, 24 (11): 1181-1190.

Breyer, Friedrich (1987): The specification of a hospital cost function. A comment on the recent literature, Journal of Health Economics, 6 (2): 147-157.

Brown, H. Shelton (2003): Managed care and technical efficiency, Health Economics, 12 (2): 149-158.

Buchanan, James M. and Robert D. Tollison (1972): Theory of public choice, University of Michigan Press: Ann Arbor.

Burgess, James F., Jr. and Paul W. Wilson (1996): Hospital ownership and technical inefficiency, Management Science, 42 (1): 110-123.

Burgess, James F., Jr. and Paul W. Wilson (1998): Variation in inefficiency among US hospitals, Canadian Journal of Operational Research and Information Processing, 36 (3): 84-102.

Busse, Reinhard and Annette Riesberg (2004): Health care systems in transition: Germany, European observatory on health care systems: Copenhagen.

Busse, Reinhard, Ulrike Nimptsch, and Thomas Mansky (2009): Measuring, Monitoring, and Managing Quality in Germany's Hospitals. Health Affairs, 28 (2): 294-304.

Button, Kenneth J. and Thomas G. Weyman-Jones (1992): Ownership structure, institutional organization and measured Xefficiency, American Economic Review, 82 (2): 439-445.

Carey, Kathleen (2000): A multilevel modelling approach to analysis of patient costs under managed care, Health Economics, 9(5): 435-446.

Carey, Kathleen (2002): Hospital Length of Stay and Cost: A Multilevel Modeling Analysis, Health Services and Outcomes Research Methodology, 3 (1): 41-56.

Carey, Kathleen and James F. Burgess, Jr. (1999): On measuring the hospital cost/quality trade-off, Health Economics, 8 (6): 509520.

Carr, John W. and Paul J. Feldstein (1967): The relationship of cost to hospital size, Inquiry, 4 (2): 45-65.

Chang, Hsihui, Wen- Jing Chang, Somnath Das, and Shu- Hsing $\mathrm{Li}$ (2004): Health care regulation and the operating efficiency of hospitals: Evidence from Taiwan, Journal of Accounting and Public Policy, 23 (6): 483-510.

Chirikos, Thomas N. and Alan M. Sear (1994): Technical efficiency and the competitive behaviour of hospitals, SocioEconomic Planning Sciences, 28 (4): 219-227.
Chirikos, Thomas N. and Alan M. Sear (2000): Measuring hospital efficiency: a comparison of two approaches, Health Services Research, 34 (6): 1389-1408.

Clarkson, Kenneth (1972): Some Implications of Property Rights in Hospital Management, Journal of Law and Economics, 15 (2): 363-384.

Cooper, William W., Lawrence M. Seiford, and Joe Zhu (2004): Sensitivity analysis in DEA, in: William W. Cooper, Lawrence M. Seiford, and Joe Zhu (eds.): Handbook on data envelopment analysis, Kluwer Academic: Boston, 75-97.

Deily, Mary E. and Niccie L. McKay (2006): Cost inefficiency and mortality rates in Florida hospitals, Health Economics, 15 (4): 419-431.

Dudley, R. Adams, Kirsten L. Johansen, Richard Brand, Deborah J. Rennie, and Arnold Milstein (2000): Selective referral to highvolume hospitals: estimating potentially avoidable deaths, The Journal of the American Medical Association, 283 (9): 1159-1166.

Dyson, R.G., R. Allen, A.S. Camanho, V.V. Podinovski, C.S. Sarrico, and E.A. Shale (2001): Pitfalls and protocols in DEA, European Journal of Operational Research, 132 (2): 245-259.

Fama, Eugene F. and Michael C. Jensen (1983): Separation of ownership and control, The Journal of Law and Economics, 26 (2): 301-325.

Feess, Eberhard and Sonja Ossig (2007): Reimbursement schemes for hospitals, malpractice liability, and intrinsic motivation, International Review of Law and Economics, 27 (4): 423441.

Feldstein, Martin Stuart (1967): Economic Analysis for Health Service Efficiency, North-Holland: Amsterdam.

Ferrier, Gary D. and Vivian G. Valdmanis (1996): Rural hospital performance and its correlates, The Journal of Productivity Analysis, 7 (1): 63-80.

Forschungsdatenzentrum der Statistischen Landesämter (2008): Krankenhausstatistik (Teil I: Grunddaten, Teil II: Diagnosen und Teil III: Kostennachweis) der Jahre 2002-2006, Antrag 8422008.

Foster, Richard W. (1974): Economic Models of the Hospital, Hospital Administration, 19 (4): 87-93.

Frey, Bruno S. and Reto Jegen (2001): Motivation crowding theory, Journal of Economic Surveys, 15 (5): 589-611.

Fried, Harold O., C.A. Knox Lovell, Shelton S. Schmidt, and Suthathip Yaisawarng (2002): Accounting for environmental effects and statistical noise in data envelopment analysis, Journal of Productivity Analysis, 17 (1-2): 157-174.

Garnick, Deborah W., Harold S. Luft, James C. Robinson, and Janice Tetreault (1987): Appropriate measures of hospital market areas, Health Services Research, 22 (1): 69-89.

Hall, Peter D. (1995): Theories and Institutions, Nonprofit \& Voluntary Sector Quarterly, 24 (1), 5-13.

Hansmann, Henry (1988): Ownership of the Firm, Journal of Law, Economics, \& Organization, 4 (2): 267-304.

Harrison, Jeffrey P., M. Nicholas Coppola, and Mark Wakefield (2004): Efficiency of federal hospitals in the United States, Journal of Medical Systems, 28 (5): 411-422. 
Helmig, Bernd and Irvine Lapsley (2001): On the efficiency of public, welfare and private hospitals in Germany over time: a sectoral data envelopment analysis study, Health Services Management Research, 14 (4): 263-274.

Herr, Annika (2008): Cost and technical efficiency of German hospitals: does ownership matter?, Health Economics, 17 (9): 1057-1071.

Hollingsworth, Bruce (2003): Non-parametric and parametric applications measuring efficiency in health care, Health Care Management Science, 6 (4): 203-218.

Hollingsworth, Bruce (2008): The measurement of efficiency and productivity of health care delivery, Health Economics, 17 (10): 1107-1128.

Jacobs, Philip (1974): A survey of economic models of hospitals, Inquiry, 11 (2): 83-97.

Jacobs, Philip and John Rapoport (2003): The economics of health and medical care, Jones and Bartlett: Sudbury, MA.

Jacobs, Rowena, Peter C. Smith, and Andrew Street (2006): Measuring efficiency in health care: analytic techniques and health policy, Cambridge University Press: Cambridge.

Koop, Gary, Jacek Osiewalski, and Mark F.J. Steel (1997): Bayesian efficiency analysis through individual effects: hospital cost frontiers, Journal of Econometrics, 76 (1-2): 77-105.

Lee, Maw Lin (1971): A conspicuous production theory of hospital behavior, Southern Economic Journal, 38 (1): 48-58.

Leibenstein, Harvey (1966): Allocative efficiency vs. X-efficiency, American Economic Review, 56 (3): 392-415.

Linna, Miika (1998): Measuring hospital cost efficiency with panel data models, Health Economics, 7 (5): 415-427.

McKay, Niccie, Mary E. Deily, and Fred H. Dorner (2003): Ownership and changes in hospital inefficiency, 1866-1991, Inquiry, 39 (4): 388-399.

Megginson, William L., Robert C. Nash, and Matthias van Randenborgh (1994): The financial and operating performance of newly privatized firms: an international empirical analysis, Journal of Finance, 49 (2): 403-452.

Morey, Richard C., David J. Fine, Stephen W. Loree, Donna L. Retzlaff-Roberts, and Shigeru Tsubakitani (1992): The trade-off between hospital cost and quality of care. An exploratory empirical analysis, Medical Care, 30 (8): 677-698.

Newhouse, Joseph P. (1970): Toward a theory of nonprofit Institutions: an economic model of a hospital, American Economic Review, 60 (1): 64-74.

Niskanen, William A. (1975): Bureaucrats and politicians, Journal of Law and Economics, 18 (3): 617-643.

Osterloh, Margit and Bruno S. Frey (2000): Motivation, knowledge transfer, and organizational forms, Organization Science, 11 (5): 538-550.

Ozcan, Yasar A., Roice D. Luke, and Cengiz Haksever (1992): Ownership and organizational performance: a comparison of technical efficiency across hospital types, Medical Care, 30 (9): 781-794.

Pauly, Mark V. and Michael S. Redisch (1973): The Not-for-Profit Hospital as a Physician's Cooperative, The American Economic Review, 63 (1): 87-99.
Pestieau, Pierre and Henry Tulkens (1990): Assessing the performance of public sector activities: some recent evidence from the productive efficiency viewpoint, Discussion Paper, Center for Operations Research and Econometrics, Université catholique de Louvain.

Picone, Gabriel, Shin-Yi Chou and Frank Sloan (2002): Are forprofit hospital conversions harmful to patients and to medicare?, RAND Journal of Economics, 33 (3): 507-523.

Pilyavsky, Anatoly I., William E. Aaronson, Patrick M. Bernet, Michael D. Rosko, Vivian G. Valdmanis and Mikhail V. Golubchikov (2006): East-west: does it make a difference to hospital efficiencies in Ukraine?, Health Economics, 15 (11): 1173-1186.

Rathgeb Smith, Steven and Kirsten A. Gronbjerg (2006): Scope and theory of government-nonprofit relations, in: Walter W. Powell and Richard Steinberg (eds.): The nonprofit sector: a research handbook, Yale University Press: New Haven, 221-242.

Rees, Ray (1988): Inefficiency, public enterprise and privatisation, European Economic Review, 32 (2-3): 422-431.

Reder, Melvin W. (1965): Some problems in the economics of hospitals, The American Economic Review, 55 (1-2): 472-480.

Rice, Rip G. (1966): Analysis of the hospital as an economic organism, Modern Hospital, 106 (4): 87-91.

Rosko, Michael D. (1999): Impact of internal and external environmental pressures on hospital inefficiency, Health Care Management Science, 2 (2): 63-74.

Rosko, Michael D. (2001): Cost efficiency of US hospitals: a stochastic frontier approach, Health Economics, 10 (6): 539-551.

Rosko, Michael D. (2004): Performance of U.S. teaching hospitals: a panel analysis of cost inefficiency, Health Care Management Science, 7 (1): 7-16.

Rosko, Michael D. and Jon A. Chilingerian (1999): Estimating hospital inefficiency: does case mix matter?, Journal of Medical Systems, 23 (1): 57-71.

Sari, Nazmi (2003): Efficiency outcomes of market concentration and managed care, International Journal of Industrial Organization, 21 (10): 1571-1589.

Scherer, Frederic M. and David Ross (1990): Industrial market structure and economic performance, Houghton Mifflin: Boston.

Schreyögg, Jonas, Oliver Tiemann, and Reinhard Busse (2006): Cost accounting to determine prices: how well do prices reflect costs in the German DRG-system?, Health Care Management Science, 9 (3): 269-279.

Schreyögg, Jonas and Constantin von Reitzenstein (2008): Strategic groups and performance differences among academic medical centers, Health Care Management Review, 33 (3): 225-233.

Shen, Yu-Chu, Karen Eggleston, Joseph Lau, and Christopher Schmid (2007): Hospital ownership and financial performance: what explains the different findings in the empirical literature?, Inquiry, 44 (1): 41-68.

Shleifer, Andrei and Robert W. Vishny (1994): Politicians and Firms, The Quarterly Journal of Economics, 109 (4): 995-1025.

Simar, Léopold and Paul W. Wilson (1998): Sensitivity analysis of efficiency scores: How to bootstrap in nonparametric frontier models, Management Science, 44 (1): 49-61. 


\section{3}

BuR - Business Research

Official Open Access Journal of VHB

Verband der Hochschullehrer für Betriebswirtschaft e.V.

Volume 2 | Issue 2 | December 2009 | 115-145

Simar, Léopold and Paul W. Wilson (2000): A general methodology for bootstrapping in non-parametric frontier models, Journal of Applied Statistics, 27 (6): 779-802.

Simar, Léopold and Paul W. Wilson (2007): Estimation and inference in two-stage, semi-parametric models of production processes, Journal of Econometrics, 136 (1): 31-64.

Sloan, Frank A. (1976): Physician fee inflation: evidence from the late 196o's, in: Richard N. Rosett (ed.): The role of health insurance in the health services sector, National Bureau of Economic Research: New York, 321-362

Sloan, Frank A. (2000): Not-for-profit ownership and hospital behaviour, in: Anthony J. Culyer and Joseph P.Newhouse (eds.): Handbook of health economics, Elsevier: Amsterdam, 1141-1174.

Staat, Matthias and Maik Hammerschmidt (2000): Benchmarking the health sector in Germany - an application of Data Envelopment Analysis, Research Paper, Institute for Market-Oriented Management, University Mannheim.

Staat, Matthias (2006): Efficiency of hospitals in Germany: a DEA-bootstrap approach, Applied Economics, 38 (19): 22552263.

Steinberg, Richard (2006): Economic theories of nonprofit organizations, in: Walter W. Powell and Richard Steinberg (eds.): The nonprofit sector: a research handbook, Yale University Press: New Haven: 117-139.

Steinmann, Lukas, Gunnar Dittrich, Alexander Karmann, and Peter Zweifel (2004): Measuring and comparing the (in)efficiency of German and Swiss hospitals, The European Journal of Health Economics, 5 (3): 216-226.

Sundararajan, Vijaya, Toni Henderson, Catherine Perry, Amanda Muggivan, Hude Quan, and William A. Ghali (2004): New ICD-10 version of the Charlson comorbidity index predicted in-hospital mortality, Journal of Clinical Epidemiology, 57 (12): 1288-1294.

Syrjänen, Mikko J. (2004): Non-discretionary and discretionary factors and scale in data envelopment analysis, European Journal of Operational Research, 158 (1): 20-33.

Villalonga, Belen (2000): Privatization and efficiency: differentiating ownership effects from political, organizational, and dynamic effects, Journal of Economic Behavior and Organization, 42 (1): 43-74.

Weisbrod, Burton A. (1988): The Nonprofit Economy, Harvard University Press: Cambridge, MA.

Wörz, Markus (2008): Erlöse - Kosten - Qualität: Macht die Krankenhausträgerschaft einen Unterschied?, VS-Verlag: Wiesbaden.

Zismer, Daniel K. (1999): Physician compensation arrangements: management \& legal trends, Aspen Publishers: Gaithersburg.

Zuckerman, Stephen, Jack Hadley, and Lisa Iezzoni (1994): Measuring hospital efficiency with frontier cost functions, Journal of Health Economics, 13 (3): 255-280.

\section{Biographies}

Oliver Tiemann, $\mathrm{MA}, \mathrm{PhD}$, is a senior research fellow at the Munich School of Management, Ludwig-Maximilians-Universität München and Helmholtz Zentrum München, Germany. He received his doctoral degree in Business Administration in 2008 from Berlin University of Technology. His research interests include health care management, performance measurement and organizational behavior.

Jonas Schreyögg, MA, $\mathrm{PhD}$, is professor for Health Services Management at the Munich School of Management, LudwigMaximilians-Universität München and Head of the Department for Health Services Management at Helmholtz Zentrum München, Germany. At the same time he is an affiliated researcher at the Stanford University's Center for Primary care and Outcomes Research. He received his doctoral degree in Economics in 2003 and his Habilitation in Business Administration and Health Economics in 2008, both from Berlin University of Technology. 